\title{
Silage review: Factors affecting dry matter and quality losses in silages ${ }^{1}$
}

\author{
G. Borreani, ${ }^{2}$ E. Tabacco, ${ }^{\star}$ R. J. Schmidt, † B. J. Holmes,ł and R. E. Muck§ \\ *Department of Agricultural, Forest and Food Sciences (DISAFA), University of Turin, Largo P. Braccini 2, 10095, Grugliasco (Turin), Italy \\ †Lallemand Animal Nutrition, Milwaukee, WI 53218 \\ †Retired, Biological Systems Engineering Department, University of Wisconsin, Madison 53706 \\ §Retired, USDA, Agricultural Research Service, US Dairy Forage Research Center, Madison, WI 53706
}

\begin{abstract}
An overview was made of dry matter (DM) and quality losses that occur during the ensiling process from the field through the feeding phase. The aim was to review the relevant published literature of the last 15 yr focusing on developments achieved after the publication of the book Silage Science and Technology. This review discusses the factors affecting DM and quality losses in terms of field and pre-ensiling conditions, respiration and temperature at ensiling, fermentation patterns, methods of covering and weighting the silage cover, and management of aerobic deterioration. The possibility of reducing DM and quality losses during the ensiling process requires knowledge of how to measure losses on farm and establish the status of the silage during the feed-out phase, implementing the most effective management practices to avoid air exposure during conservation and reduce silage aerobic deterioration during feeding. The paper concludes with future perspectives and recommended management practices to reduce losses and increase efficiency over the whole ensiling process in view of increasing sustainability of the livestock production chain.
\end{abstract}

Key words: dry matter loss, silage management, respiration, fermentation, aerobic deterioration

\section{INTRODUCTION}

Producing high-quality forage as silage, while avoiding DM losses as much as possible, is a challenge. The silage-making process is commonly divided in 4 phases: (1) the initial aerobic phase in the silo immediately after harvest, (2) the fermentation phase, (3) the stable storage phase in the silo, and (4) the feed-out phase when the silo feed face is open and the material is ex-

Received September 14, 2017.

Accepted November 21, 2017.

${ }^{1}$ This article is part of a special issue on silage management.

${ }^{2}$ Corresponding author: giorgio.borreani@unito.it posed to air immediately before, during, and after its removal from the silo (Wilkinson and Davies, 2013). Dry matter losses and quality changes occur during each of these stages of the ensiling process, reducing the quality of the as fed product. The main stages where losses occur are field harvesting, silo respiration and fermentation, effluent production, and oxygen exposure during storage and feed-out phases. Figure 1 reports the minimum value of the DM losses that occur in each stage when good management practices are used and high values of loss when less than good management is performed or no coverings are used (Borreani et al., 1999; Bichert et al., 2000; Rankin and Undersander, 2000; Jones, 2001; Muck et al., 2003; Rotz, 2005). Although some losses are unavoidable, good management practices can reduce or compensate for these losses to provide the quality forage needed for each animal group (Rotz, 2003). Best management practices are described later.

\section{FACTORS AFFECTING DM LOSSES}

\section{Field and Pre-Ensiling Conditions}

All forages not directly harvested and conserved need a field wilting period to reduce their moisture concentration, to enhance their ensilability characteristics (i.e., increase as-fed concentration of water-soluble carbohydrates and reduce water activity) and avoid seepage losses from the silo. The major field processes involved in crops that are wilted are mowing, dry down (wilting), and baling or chopping, with DM losses and quality changes occurring during each of these processes, reducing the quality of the final product (Rotz, 2003).

Achieving a rapid wilting in the field is essential for reducing DM and nutritive value losses. Conditioning the forage and spreading the crop immediately after cutting has a major effect on the drying rate of forage (Wilkinson et al., 2003). Dry matter losses, especially leaves, were directly related to the forage DM content at the time of treatment and the severity of the conditioning. 


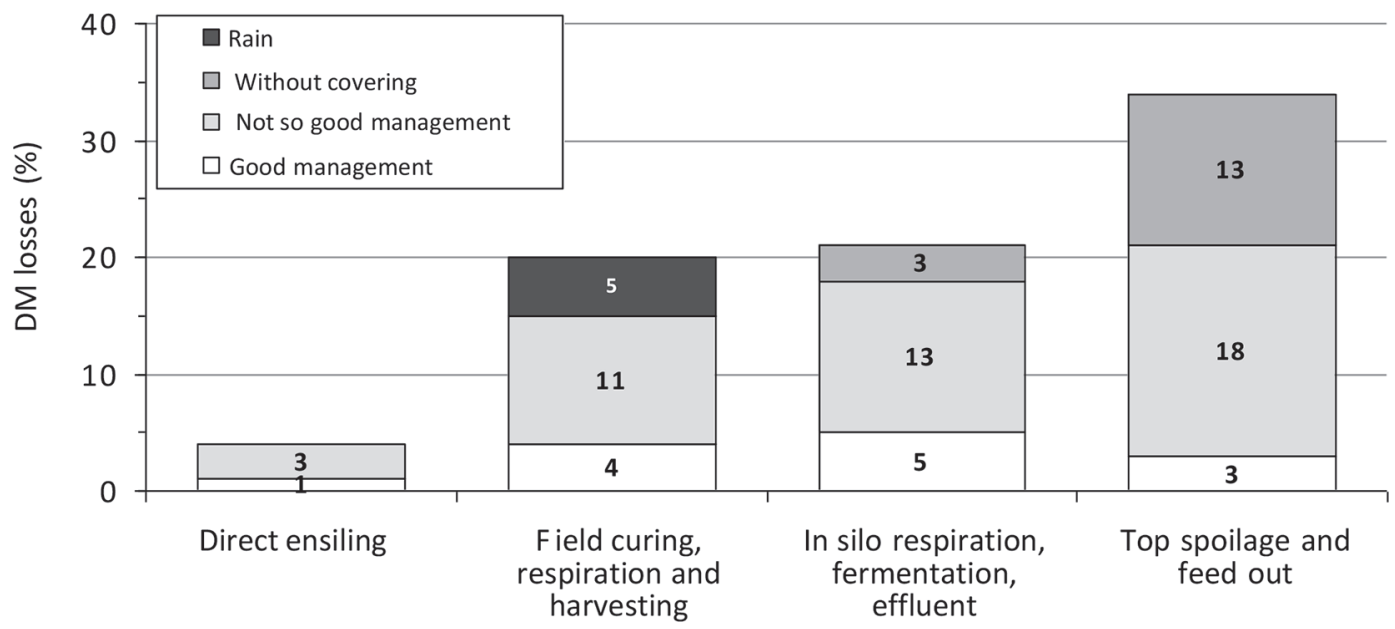

Figure 1. Potential DM losses during silage-making stages. The white portion of bar graph indicates when good management practices are used; the light gray portion is the range of additional losses associated with nonoptimal management practices; and the dark gray portion is the additional losses when no covering is applied (based on Borreani et al., 1999; Bichert et al., 2000; Rankin and Undersander, 2000; Jones, 2001; Muck et al., 2003; Rotz, 2005).

Borreani et al. (1999), evaluating the conditioning effect on drying rate of Italian ryegrass and alfalfa forages in the field, found that DM losses at cutting were always lower than $2.0 \%$ for Italian ryegrass even in the more severe conditioning treatments. Whereas in alfalfa, DM losses due to mowing ranged from 0.3 to $1.4 \%$ for conventional mowers and from 3.4 to $11.7 \%$ for mower-conditioners. This led to a loss of more than $20 \%$ of the $\mathrm{CP}$ at mowing in alfalfa conditioned with more severe conditioning using steel flails. They concluded that the most severe conditioning (steel flails) followed by tedding is appropriate for grass, as it significantly reduces the wilting time without significantly affecting DM losses. However, a less severe conditioning (rubber rolls) without tedding is more appropriate for wilting alfalfa to avoid excessive leaf and protein loss.

Borreani et al. (1999) evaluated field DM losses from cutting to baling of alfalfa harvested at approximately 40 or $65 \%$ DM (Figure 2). Data showed that DM losses under good drying conditions without tedding were mainly due to conditioning treatment, with mechanical losses being highest for flail conditioning. However, field respiration losses during drying followed the opposite trend with losses of $2.0,1.5$, and $1.2 \%$ for no, roll, and flail conditioning, respectively.

Kung et al. (2010) compared wide $(1.52 \mathrm{~m})$ to narrow $(1.20 \mathrm{~m})$ swathing of alfalfa, finding wide swathing saved approximately $22 \mathrm{~h}$ of wilting time to reach $45 \%$

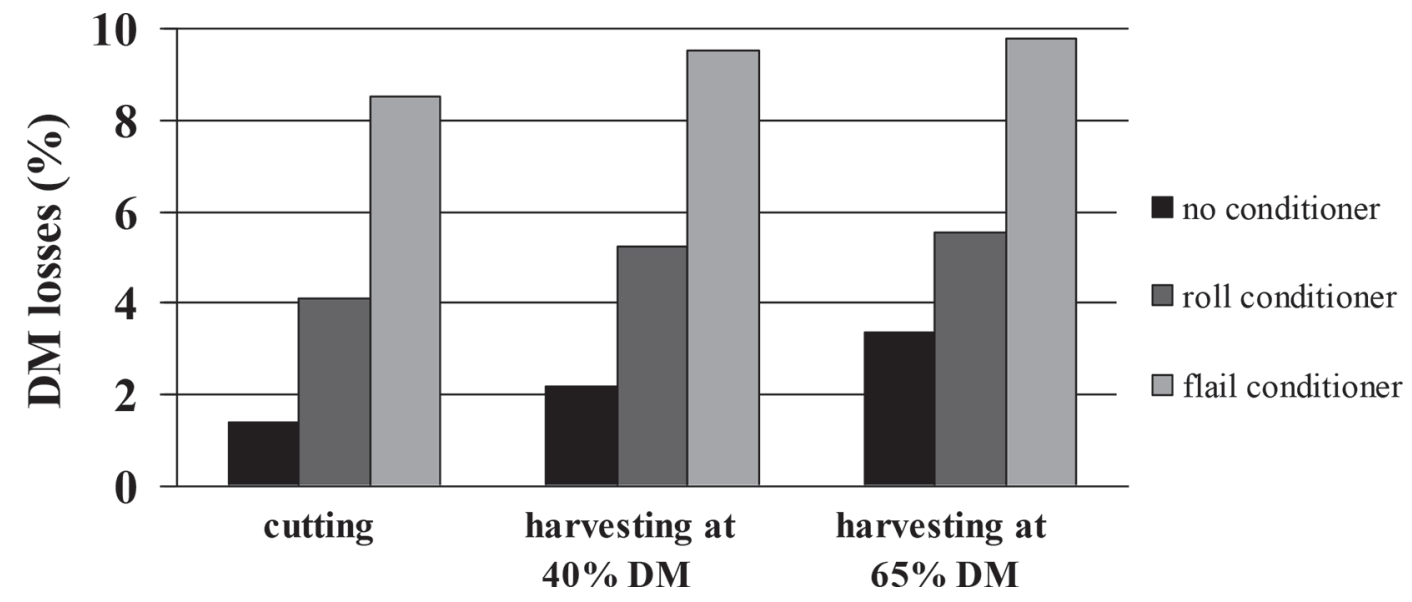

Figure 2. Dry matter losses (\%) due to mechanical treatments of an untedded alfalfa forage at 3 different times during drying (data adapted from Borreani et al., 1999). 
DM. Although soluble sugar content was increased by wide swathing, no major effect was observed on silage fermentation. Thomas (2013) reported drying times were reduced from 60 to $80 \%$ in wide swathed alfalfa and wide swathing increased milk per tonne of forage by 20 and $11 \%$ for first and second cuttings, respectively. When wide swathing forages, there is a greater chance of driving over the swath and unavoidable effect of wheel traffic on alfalfa regrowth, which leads to yield losses (Kung et al., 2010). Undersander (2006) reported the detrimental effect of traffic on alfalfa yield, with yield losses ranging from 2 to $11 \%$ and from 9 to $30 \%$ for wheel traffic at 2 and $5 \mathrm{~d}$ after mowing, respectively.

It is well known that forage legumes can have a fairly low water-soluble carbohydrate-to-buffering capacity ratio; consequently, increasing the concentration of fermentable carbohydrates in the crop is imperative to avoid DM losses due to poor fermentation. Some recent research suggested cutting in the morning to maximize dry down in a short period instead of leaving the forage respiring over extended periods and vulnerable to rain (Kung et al., 2010; Tremblay et al., 2014). In contrast, many other studies in the past decade looked at mowing in the afternoon to increase sugar content in the plant due to photosynthesis activity. Cutting alfalfa in the afternoon increased the content of simple carbohydrates before wilting by 17,18 , and $22 \%$ in spring, summer, and fall, respectively, compared with cutting the forage in the morning (Morin et al., 2012). This difference continued throughout the wilting period. Brito et al. (2008) noticed that alfalfa mowed in the afternoon had higher content of total nonstructural carbohydrates in bale silage than morning-mowed alfalfa. Additionally, cows fed afternoon-mowed alfalfa silage had significantly greater feed intake and milk yield. Thomas (2007) showed numerical differences in plant sugars comparing morning versus afternoon harvested alfalfa before wilting. However, when the DM concentration reached approximately $40 \%$, these small differences decreased and sometimes disappeared.

\section{Respiration and Temperature at Ensiling}

Before the active fermentation phase can begin, oxygen trapped in the packed forage allows biological and chemical processes that consume nutrients and energy, leading to the production of water, carbon dioxide, heat and free ammonia (McAllister and Hristov, 2000). This increases silage temperature and negatively affects the silage, both in terms of DM and quality losses (Holmes, 2006). Rees (1982) reported DM losses of $1.7 \%$ for every $10^{\circ} \mathrm{C}$ increase in temperature in laboratory scale silos. Heat production is normal during the ensiling process and a rise up to $12^{\circ} \mathrm{C}$ in relation to silage temperature at harvesting is common even in a well-managed silo (Adesogan and Newman, 2014). Depending on ambient temperatures when the forage was harvested, temperatures up to $40^{\circ} \mathrm{C}$ have been found, especially in tropical areas (Adesogan, 2009) and in crops ensiled in summer in temperate climates (Kung, 2011). Ensiling at high temperatures or in wet conditions is known to increase the rate of DM losses before silo sealing (Weinberg et al., 2001; Ashbell et al., 2002). Kim and Adesogan (2006), studying the concurrent effects of high ensiling temperatures, surface moisture due to rainfall at harvest, and delayed silo sealing, indicated the fermentation of corn silage is adversely affected by wet conditions at harvest and high ensiling temperatures, whereas delaying silo sealing for $3 \mathrm{~h}$ caused no adverse effects.

At ensiling, chopped forage is still metabolically active and respires while oxygen is available. Plant tissue respiration is the primary driver for removing oxygen from the silo and producing heat, although respiration by aerobic microorganisms can contribute. At DM contents of 30 and $50 \%$, respiration rates are about 70 and $30 \%$ of maximum, respectively. Respiration rate peaks at $46^{\circ} \mathrm{C}$, but the enzymes responsible are inactivated at $54^{\circ} \mathrm{C}$ (Pitt et al., 1985).

Prolonged temperatures above $40^{\circ} \mathrm{C}$ can cause protein damage (denaturation), affecting the availability of AA at feeding of most legume and grass forages. Denaturation occurs slowly below $38^{\circ} \mathrm{C}$, doubling with each $14^{\circ} \mathrm{C}$ increment above that threshold (Muck and Pitt, 1993). Prolonged high temperatures may lead to extensive browning and decreased intake and digestibility. Proteolysis, the breakdown of plant proteins to free AA, peptides, and ammonia, is also affected by temperature, with rates doubling for every $10^{\circ} \mathrm{C}$ increase between 10 and $38^{\circ} \mathrm{C}$ (Muck and Dickerson, 1988). A rapid and efficient fermentation reduces proteolysis; thus, using microbial inoculants with fast growing homolactic bacteria is a recommended practice, especially in warm and humid ambient conditions (Muck and Pitt, 1993).

Growth rates of the lactic acid bacteria (LAB) essential to the initial ensiling fermentation are also affected by temperature, among other parameters (e.g., availability of sugars, degree of anaerobiosis, and moisture levels). Lactic acid bacteria grow most rapidly at temperatures between 27 and $38^{\circ} \mathrm{C}$. Below $27^{\circ} \mathrm{C}$, their growth is slower, but most fermentations should be complete between 7 to $10 \mathrm{~d}$ at these temperatures (Yamamoto et al., 2011).

Slow silo filling and delayed silo sealing also negatively affect silage quality. Brüning et al. (2018) reported the effects of delaying sealing of corn silage laboratory 
Table 1. Losses of DM and gross energy from some silage fermentation pathways (McDonald et al., 1991; Rooke and Hatfield, 2003) ${ }^{1}$

\begin{tabular}{|c|c|c|c|c|c|}
\hline Organism & Pathway & Substrate & Products & \multicolumn{2}{|c|}{ Loss (\% substrate) } \\
\hline $\mathrm{LAB}$ & Ho & Glucose & 2 lactate & 0 & 0.7 \\
\hline LAB & $\mathrm{He}$ & 3 Fructose & 1 lactate, 1 acetate, 2 mannitol, $1 \mathrm{CO}_{2}$ & 4.8 & 1.0 \\
\hline LAB & $\mathrm{Ho} / \mathrm{He}$ & 2 Citrate & 1 lactate, 3 acetate, $3 \mathrm{CO}_{2}$ & 29.7 & -1.5 \\
\hline LAB & $\mathrm{Ho} / \mathrm{He}$ & Malate & 1 lactate, $1 \mathrm{CO}_{2}$ & 32.8 & -1.8 \\
\hline Yeasts & & Glucose & 2 ethanol, $2 \mathrm{CO}_{2}$ & 48.9 & 0.2 \\
\hline
\end{tabular}

${ }^{1} \mathrm{LAB}=$ lactic acid bacteria; Ho $=$ homofermentative; He = heterofermentative.

silos with a low packing density (191 $\mathrm{kg}$ of $\left.\mathrm{DM} / \mathrm{m}^{3}\right)$. Delaying sealing by $4 \mathrm{~d}$ led to DM losses of up to $11 \%$, an increase in yeast counts, and a decline of up to $65 \%$ in water-soluble carbohydrates in silages. Delayed sealing also promoted the formation of ethyl esters during fermentation, which can have a negative effect on feed intake by ruminants, as partly shown in the study of Gerlach et al. (2013). Likewise, Nutcher et al. (2015) noted a 1-d delay in sealing increased OM losses by $27.2 \%$ in the top $45 \mathrm{~cm}$ of corn silage under farm-scale conditions compared with immediate sealing (156 vs. $123 \mathrm{~g} / \mathrm{kg}$ of OM loss).

Although generally thought of as anaerobes, most LAB can grow under aerobic conditions, consuming molecular oxygen and helping to create anaerobic conditions in the plant mass (Yamamoto et al., 2011). Furthermore, evidence indicates that air influences the metabolism of some LAB (Condon, 1987), and a reduction in lactic acid production has been reported (Kim and Adesogan, 2006). An increase in the activity of enterobacteria and heterolactic fermentation can also be seen in silages where packing or sealing is delayed (Mills and Kung, 2002; Weiss et al., 2016), which leads to an increase in acetic acid concentration.

\section{Fermentation Patterns}

As the silo becomes anaerobic, various anaerobic and facultative microorganisms increase in population and ferment primarily sugars and organic acids in the crop. The principal fermentative microbial groups include LAB, enterobacteria, clostridia, and yeasts (Pahlow et al., 2003).

The losses associated with fermentation in the silo are primarily from carbon dioxide production. These losses typically are in the range of 2 to $4 \%$ (Zimmer, 1980). The amount of DM loss from fermentation depends on the dominant microbial species and the substrates fermented. Many of the fermentation pathways have been known for decades, and common pathways are listed in Table 1. The LAB that ferment glucose homofermentatively produce only lactate so no DM loss occurs, whereas LAB that ferment glucose heterofermentatively produce $1 \mathrm{~mol}$ of carbon dioxide per mol of glucose, leading to $24 \%$ DM loss but only a $1 \%$ increase in gross energy loss from the silage. If a LAB species ferments citrate or malate, carbon dioxide is produced, with concomitant DM losses, whether the LAB strain is homo- or heterofermentative when fermenting glucose.

As indicated in Table 1, if microorganisms other than LAB play a significant role in fermentation, DM loss in the form of carbon dioxide is generally large. This is particularly true for yeasts producing ethanol from glucose (e.g., sugarcane silage) or clostridia producing butyrate from lactate or glucose. A portion of the DM loss from clostridial fermentation of glucose or lactate is the production of hydrogen gas, the primary reason for higher gross energy losses from clostridial activity.

More recently, there has been considerable interest in Lactobacillus buchneri, a heterofermentative LAB species, as an inoculant species to promote aerobic stability (Driehuis et al., 1999). This microorganism can anaerobically degrade $1 \mathrm{~mol}$ of lactate without an electron acceptor to a half mole of acetate, a half mole of 1,2-propanediol, and a half mole of carbon dioxide (Oude Elferink et al., 2001), resulting in approximately $1 \%$ DM loss compared with untreated silage based on a survey of laboratory-scale silages (Kleinschmit and Kung, 2006). At field scale, improved aerobic stability from L. buchneri treatment should compensate for the modestly increased fermentation losses as discussed later. Some L. buchneri-treated silages contain elevated propionate levels compared with untreated silages (e.g., Driehuis et al., 1999), but Oude Elferink et al. (2001) found no mechanism in L. buchneri to account for that observation. Subsequently, Krooneman et al. (2002) discovered a new LAB species, Lactobacillus diolivorans, in corn silage that was capable of degrading 1,2-propanediol to approximately equal quantities of propionate and 1-propanol. 
Without the use of silage additives, the fermentation process is a result of the activity of the epiphytic microorganisms on the crop at ensiling. The populations of various microbial groups on crops at ensiling are influenced by the crop, growing conditions, environmental factors during wilting, and so on (Pahlow et al., 2003; Muck et al., 2003). Enterobacteria are often at higher populations than LAB at ensiling and thus influence early fermentation in the silo (Pahlow et al., 2003). McEniry et al. (2010) found enterobacteria to be more prevalent than LAB in perennial ryegrass at ensiling and in the first days of fermentation, and the enterobacteria maintained a higher level longer at a DM concentration of $40.6 \%$ than at $18.5 \%$. In a second experiment, neither degree of compaction nor air infiltration influenced the dominant microbial species during the ensiling of unwilted perennial ryegrass. Parvin and Nishino (2009) studied the differences in guinea grass ensiled at 28.6 and $44.3 \%$ DM. At $15 \mathrm{~d}$, denaturing gradient gel electrophoresis indicated Lactobacillus brevis and Lactococcus lactis were the dominant bacteria in the wetter silage, whereas the drier silage contained Lactobacillus plantarum in addition to the other 2 . However, the lactate-to-acetate ratio was higher in the wetter silage, indicating the fermentation in the wetter silage was more homofermentative. Both silages also had significant denaturing gradient gel electrophoresis bands, suggesting influence of Bacillus species on fermentation.

Temperature of the crop affects both the speed of fermentation and the microbial species that dominate fermentation. As indicated above, LAB grow most rapidly at temperatures between 27 and $38^{\circ} \mathrm{C}$ (Yamamoto et al., 2011). Kim and Adesogan (2006) ensiled corn at 40 and $20^{\circ} \mathrm{C}$, showing higher ensiling temperatures lowered the contents of lactic and acetic acids. In addition, ensiling at $40^{\circ} \mathrm{C}$ increased the levels of ammonia- $\mathrm{N}$ and acid detergent insoluble CP. The higher temperature reduced yeast counts in the silages at opening but had no effect on mold counts. Some research results show a trend for high temperature during ensiling to decrease yeast counts in silages over the storage period more than lower temperature. Kim and Adesogan (2006), working on corn silage, found less yeasts in silages stored at $40^{\circ} \mathrm{C}$ than in silages stored at $20^{\circ} \mathrm{C}$, after $82 \mathrm{~d}$ of storage. The magnitude of the effects was more pronounced in study on corn silage from Weiss et al. (2016), who reported lower yeast count associated with higher aerobic stability in promptly sealed silages stored at higher temperatures ( 35 vs. $\left.20^{\circ} \mathrm{C}\right)$. Zhou et al. (2016) reported that, with conservation temperature of 20 and $25^{\circ} \mathrm{C}$, yeast number was under detection level after $60 \mathrm{~d}$ of storage in corn silages, whereas similar number of yeasts, about $4 \log _{10} \mathrm{cfu} / \mathrm{g}$, persisted at 15 , 10 , and $5^{\circ} \mathrm{C}$. A possible explanation is that high ambient temperature during storage enhances acetic acid production (Wang and Nishino, 2013) by favoring the development of L. buchneri (Zhou et al., 2016), whereas lower environmental temperature could indirectly favor the yeast survival by allowing a slower metabolism and a reduced permeability of the cell membrane to organic acids (Zhou et al., 2016). Villa et al. (2010) studied fermentation of 2 corn cultivars grown in climates of different temperature and ensiled at temperatures reflective of typical harvest conditions $\left(16\right.$ and $\left.37^{\circ} \mathrm{C}\right)$. The warmer climate cultivar had higher initial levels of LAB and fermented more rapidly. The active fermentation period in the warmer cultivar included contributions from Pediococcus, Leuconostoc, and Lactobacillus species, whereas Pediococcus and Lactobacillus were dominant in the cooler cultivar silage. In spite of differences in microbial species, lactate to acetate ratios were high, 5.0, in both silages. Pauly and Spörndly (2011) ensiled corn at 6,12 , and $18^{\circ} \mathrm{C}$ in one year and at $2.6,6,12$, and $20^{\circ} \mathrm{C}$ the second year. At $6^{\circ} \mathrm{C}$, the silages were at $\mathrm{pH} 4.1$ by $60 \mathrm{~d}$ of fermentation, but these silages were lower in lactate and acetate and higher in ethanol than silages stored at higher temperature. Most recently, Zhou et al. (2016) ensiled corn at $5,10,15,20$, and $25^{\circ} \mathrm{C}$. At 20 and $25^{\circ} \mathrm{C}$, initial fermentation was dominated by $L$. plantarum and Pediococcus pentosaceus, but by d $7, L$. buchneri appeared and was dominant at the last sampling time, $60 \mathrm{~d}$. At 5 and $10^{\circ} \mathrm{C}$, Lactobacillus coryneformis was initially highest, giving way to Leuconostoc citreum, Lactobacillus sakei, and Lactobacillus curvatus. At $60 \mathrm{~d}$, the lactate-to-acetate ratio was highest at $5^{\circ} \mathrm{C}$ and lowest at $25^{\circ} \mathrm{C}$, reflective of the activity of $L$. buchneri in the warmer silages. In this study, ethanol was not affected by storage temperature. These 4 studies indicate considerable variation in results by location, and further study is needed to understand microbial dynamics both before and during ensiling.

After fermentation is complete, the silage stabilizes and the temperature starts to slowly decrease, influenced by ambient temperatures and silo size. During the storage phase, silage temperature in the silo core was reported to range from 12 to $26^{\circ} \mathrm{C}$ in Italy (Borreani and Tabacco, 2010). Core temperature varied according to the amount of forage ensiled and the type of storage structure. Kung (2011) reported core temperature of $32^{\circ} \mathrm{C}$ after $90 \mathrm{~d}$ in corn silage in Wisconsin. Silages can be found to be relatively hot $\left(>38^{\circ} \mathrm{C}\right)$ even after 4 to 6 wk (or more), especially those harvested dry (>40\% DM) and poorly packed (Kung, 2011).

Elimination of fermentation losses is not possible, but the use of silage additives may help minimize them. 
A common additive in northern Europe is formic acid, which is used in making unwilted or lightly wilted grass silages (Kung et al., 2003). The initial reduction in $\mathrm{pH}$ by acid addition favors the LAB and reduces the activity of enterobacteria and clostridia. Formic acid, on average, reduced $\mathrm{pH}$ as well as lactate, acetate, and butyrate production. However, ethanol production and effluent losses were increased so DM losses were similar between untreated and formic acid-treated silages.

Of the bacterial silage inoculants, homofermentative LAB should be the most effective at minimizing carbon dioxide losses during the initial ensiling fermentation as suggested in Table 1. The LAB inoculants have been developed to rapidly grow and lower $\mathrm{pH}$ in silage so they dominate fermentation (Kung et al., 2003). Reviews (e.g., Muck and Kung, 1997; Oliveira et al., 2017) indicate homofermentative inoculants are successful in reducing $\mathrm{pH}$ and shifting fermentation toward lactate in the majority of studies. Improvements in DM recovery were observed less often than effects on $\mathrm{pH}$, but Muck and Kung (1997) reported DM recovery was 6 percentage points higher in inoculated silage than untreated in the studies where DM recovery was affected by the inoculant. Oliveira et al. (2017) found improved DM recovery (average of 2.8 percentage points, $\mathrm{n}=17$ ) from inoculation of temperate and tropical grass silages but no improvement in corn and sorghum silages $(\mathrm{n}=18)$. Overall, it appears homofermentative LAB inoculants are able to reduce fermentation losses even though it is not possible to experimentally separate fermentation losses from other DM losses.

\section{Storage Phase}

Providing an effective seal on silos and silage piles is crucial to minimizing DM losses during the storage period. The value of a seal was shown by Bolsen et al. (1993) comparing uncovered and polyethylene (PE)covered bunker and pilot-scale silos (Table 2). Without a cover, the losses in the top $0.5 \mathrm{~m}$ were large. Feeding a ration including only $5 \%$ on a DM basis of a silage that has undergone such spoilage is detrimental to livestock, reducing intake and digestibility of the whole ration (Bolsen et al., 2001). So, in essence, this material is either a total loss or if fed, costs the producer in the form of reduced livestock performance and potentially detrimental health effects.

An effective seal consists of 2 factors: (1) a barrier with a low permeability to oxygen between the crop and air and (2) how well the barrier is secured to the crop, to the silo structure (walls, floor, and so on) and to itself where multiple sheets of the barrier are required for large storage structures. In the 20th century,
PE film was the primary means of sealing the open surfaces of all silo types. As indicated in Table 2, PE film in pilot-scale research can provide a barrier with losses that do not vary by depth, indicating PE film is capable of providing a good seal. Practically, as shown by the bunker silo results in Table 2, elevated losses in the $25 \mathrm{~cm}$ immediately under the film are common. Various alternative plastic films have become available to producers in the 21st century that provide a better oxygen barrier (OB) than PE. The effectiveness of these films compared with $\mathrm{PE}$ will be discussed later (Plastic Cover section).

Some studies have shown the new films are not always effective (Wilkinson and Fenlon, 2014). These failures may be explained by improper management to exclude air from entering under the plastic: (e.g., joints in film sheets, joints of film and wall, joints of film and ground, and punctures in the plastic film). Air can also enter under the plastic cover at the edge where it is cut to allow silage removal from the silo. Borreani et al. (2008) stated "During feed-out, air can penetrate the peripheral areas of a silo up to $4 \mathrm{~m}$ from the feed-out face, especially when the sealing cover is not weighted down or is only weighted with tyres." Referring to an unweighted plastic cut edge, Robinson and Swanepoel (2016) found "... silage as far as $7 \mathrm{~m}$ from the exposed face had deteriorated, at least in the outer $25.4 \mathrm{~cm}$ core...." Thus, it is recommended the cut plastic edge is uniformly and heavily weighted to limit air from entering between the plastic film and the silage during silage feed-out.

Plastic top sheets should be uniformly weighted to hold the plastic in contact with the silage. Weighting materials which have been used include whole tires, tire sidewalls, gravel-filled bags, loose soil/sand/gravel,

Table 2. Dry matter losses (\%) in the top of bunker and pilot-scale silos (Bolsen et al., 1993)

\begin{tabular}{|c|c|c|c|c|}
\hline \multirow[b]{2}{*}{ Cover } & \multirow{2}{*}{$\begin{array}{c}\text { Depth } \\
(\mathrm{cm})\end{array}$} & \multicolumn{3}{|c|}{ DM loss $(\%)$} \\
\hline & & Alfalfa & Corn & Sorghum \\
\hline \multicolumn{5}{|l|}{ Bunker silos } \\
\hline \multirow[t]{3}{*}{ Uncovered } & 25 & 78.8 & 80.4 & 77.0 \\
\hline & 50 & 23.4 & 29.4 & 53.2 \\
\hline & 75 & 14.6 & 19.2 & 20.2 \\
\hline \multirow[t]{3}{*}{ Polyethylene } & 25 & 7.2 & 22.5 & 21.3 \\
\hline & 50 & 1.6 & 9.1 & 6.7 \\
\hline & 75 & 5.78 & 12.3 & 6.7 \\
\hline \multicolumn{5}{|l|}{ Pilot-scale silos } \\
\hline \multirow[t]{3}{*}{ Uncovered } & $0-33$ & 66.1 & 64.3 & 62.3 \\
\hline & $33-67$ & 40.9 & 37.9 & 34.2 \\
\hline & $67-100$ & 35.7 & 16.6 & 7.4 \\
\hline \multirow[t]{3}{*}{ Polyethylene } & $0-33$ & 7.7 & 14.8 & 13.5 \\
\hline & $33-67$ & 7.7 & 13.0 & 7.9 \\
\hline & $67-100$ & 8.5 & 13.9 & 5.4 \\
\hline
\end{tabular}


and organic materials. Tarpaulins have been used to distribute the weighting effect of intermittent weighting materials such as gravel bags. The tarpaulins also provide protection from physical and UV light damage to the plastic film. The purpose of uniform weighting is to limit how air moves between the plastic and silage. Uniform weighting also helps to limit billowing of the plastic when exposed to winds. Billowing has the effect of pumping air through poorly sealed joints in the plastic into the space between the plastic and silage. Billowing also has the effect of moving weighting materials down slopes, thus leaving some areas unweighted.

Although there may be ample anecdotal evidence of the importance of weighting the film properly, there are relatively few research data to confirm its effect on preservation. In a survey of 30 commercial bunker silos, Ruppel et al. (1995) found the silage temperature $20 \mathrm{~cm}$ below the film and ADIN concentration in that silage were negatively correlated with tire density, suggesting low tire density permitted more oxygen entry. Dry matter losses were positively, but not significantly, correlated with tire density.

Similarly to weighting of the film, recommendations at the interfaces of film sheets are generally based on anecdotal evidence. Where plastic sheets meet, an overlap of at least $1.2 \mathrm{~m}$ should be provided and highdensity weighting material should be applied (Bolsen, 2006). The plastic up-slope from the overlap should be on top of the down-slope sheet to discourage runoff water from entering the silage. Where the plastic meets the ground, either at the sides and ends of a silage pile or at the ends of a bunker silo, the plastic should extend at least $1.2 \mathrm{~m}$ onto the floor and be uniformly weighted (Bolsen, 2006). Windrows of soil/sand/gravel or gravelfilled bags have been used effectively to accomplish this seal (Bolsen, 2006). The floor should slope to drain runoff water away from the silage.

Silage at the top surface near bunker silo walls is notorious for excessive spoilage. Borreani and Tabacco (2010), in a survey of 54 corn silage bunker silos, noted elevated temperatures at the top of the silo near the wall even in silos with no visible spoilage under the film. This is because it is almost impossible to seal this joint to exclude air and runoff water. Recently, the practice of lining the walls of bunker silos with plastic and lapping at least $1.2 \mathrm{~m}$ of the plastic over the top of the forage when the silo is full and then applying a top layer of plastic over the lapped plastic has proven an effective way to seal that joint (Bolsen, 2006). Muck and Holmes (2009) showed losses were lower and fermentation products were higher when the wall was lined with plastic compared with when a top cover of plastic alone was held against the bunker silo wall with gravel-filled bags. Borreani and Tabacco (2014) compared 200- $\mu \mathrm{m}$ $\mathrm{PE}$ to a $130-\mu \mathrm{m}$ OB film in 2 farm bunker silos where the walls were lined with the same films used for the top cover. Even using film down the wall, samples in the upper parts of the silo near the wall showed higher DM losses than those far from the wall. There was also a significant interaction of film type and distance from the wall, with the difference in DM losses relative to the wall smaller using the OB film. Lima et al. (2017) evaluated 2 covering systems in 8 dairy farm bunker silos: an OB film ( $45 \mu \mathrm{m}$ thick) on the walls, which extended approximately $2 \mathrm{~m}$ over the top, compared with no wall film. Both treatments had a single layer of standard PE film $(180 \mu \mathrm{m}$ thick $)$ top cover. The shoulder silage under the OB film was similar to that in the central core of the silo (positive control) and significantly better than the shoulder silage under the standard covering system, with lower counts of spoilage microorganisms, lower DM loss, and greater estimated milk per tonne of silage. These effects were more pronounced at 0 to 101 cm from the wall (Lima et al., 2017).

Punctures in the plastic can occur at any time from a wide variety of sources. The sooner punctures are found and sealed, the less time silage is exposed to oxygen and the less deterioration will occur (Green et al., 2012). Methods of limiting the occurrence and size of punctures include proper footwear for workers walking on the plastic, tarpaulins, increased tensile strength plastics, and scrim embedded in the plastic. Periodic inspection of the plastic and patching holes with tape designed for the specific plastic is important to minimize spoilage.

Another type of loss during the conservation phase is effluent. These losses, that typically range from 0.2 to $0.5 \%$, are reviewed in detail by Savoie and Jofriet (2003). These authors reported silage DM content and silo type and size as the main drivers to predict effluent losses and that effluent is prevented in most cases at DM content greater than $35 \%$.

\section{Aerobic Deterioration}

Aerobic deterioration of silages during the feed-out phase is a significant problem for farm profitability and feed quality worldwide (Berger and Bolsen, 2006; Borreani and Tabacco, 2010). In contrast to the surface losses occurring during storage, air exerts a stronger effect during the feed-out phase because exposure of the silage to oxygen is inevitable once the silo is opened, and air can penetrate via the silage face, up to distances of $4 \mathrm{~m}$, especially in the periphery of the silo (Pahlow et al., 2003; Borreani et al., 2007; Vissers et al., 2007). The greater penetration in the periphery is 
due to the higher porosity of the silage in these areas, and movement of oxygen is proportional to porosity (Pitt and Muck, 1993).

Much research effort has been placed on understanding the fermentation and stable phases of ensiling as well as silage additives aimed at improving the efficiency of fermentation (McDonald et al., 1991; Kung et al., 2003). It is now recognized that the changes during the feed-out phase are equally as important as those in the closed silo from the viewpoint of preserving nutrients and maintaining good hygienic quality of the silage (Borreani and Tabacco, 2010; Driehuis, 2013; Wilkinson and Davies, 2013). A large part of the effort made to produce high yields per hectare of high-quality silages is negated if aerobic deterioration occurs.

The general pattern of aerobic deterioration has been known for approximately 3 decades (Wilkinson and Davies, 2013). When oxygen is introduced to silage, aerobic microorganisms begin to grow, initially respiring soluble substrates and then more complex compounds. Yeasts are generally the initiators of aerobic deterioration, consuming sugars and fermentation acids and raising silage temperature and $\mathrm{pH}$ (Pahlow et al., 2003). With increased $\mathrm{pH}$, bacilli and other aerobic bacteria grow, increasing temperature further. Finally, molds complete the silage deterioration. In corn silage, acetic acid bacteria have been found to be initiators of aerobic deterioration in some cases, and the reasons are not yet fully understood (Spoelstra et al., 1988; Dolci et al., 2011). This deterioration process involves, to different extents, up to $20 \%$ of the total stored DM of farm silages, both in temperate (Vissers et al., 2007; Borreani and Tabacco, 2010; Schmidt and Kung, 2010) and warm climates (Huisden et al., 2009; Kang et al.,
2009; Weinberg et al., 2009; Bernardes et al., 2012). The losses could reach $70 \%$ of the stored DM in the peripheral areas and near the sidewalls of the bunkers and are related to the depletion of the digestible carbohydrate and organic acid fractions (Bolsen et al., 1993; Borreani et al., 2007; Bernardes et al., 2012), with the most digestible materials being used up first.

Summarizing results for the relationship between DM losses and mold count in spoiling farm silages in the last decade (Borreani et al., 2007; Bernardes et al., 2012; Lättamäe et al., 2012; Borreani and Tabacco, 2012a, 2014; Lima et al., 2017), when the mold level in the silage was greater than $5 \log _{10} \mathrm{cfu} / \mathrm{g}$ (i.e., mold becomes visible on the silage), the DM losses are greater than $20 \%$. When mold counts exceeded $6 \log _{10} \mathrm{cfu} / \mathrm{g}$ of silage, losses could exceed $40 \%$ of the original ensiled DM (Figure 3). Furthermore, when the mold count rose to over $5 \log _{10} \mathrm{cfu} / \mathrm{g}$ of silage, substantial changes in nutritional quality occurred, with starch content beginning to decrease, falling below $10 \%$ of $\mathrm{DM}$ when the mold count was higher than $7 \log _{10} \mathrm{cfu} / \mathrm{g}$ of silage. The decrease in nutritional quality, coupled with the DM losses, results in a dramatic decrease in the potential milk production of the original harvested crop, as estimated with the MILK2006 spreadsheet (Shaver et al., 2006). Tabacco et al. (2011b) related the estimated milk yield per tonne of harvested DM to mold count after air exposure in corn and sorghum silages. They showed reductions in potential milk production when the mold count exceeded $4 \mathrm{log} \mathrm{cfu} / \mathrm{g}$ of silage, and it was almost halved when the mold count was greater than $8 \mathrm{log} \mathrm{cfu} / \mathrm{g}$ of silage.

Unfortunately, with on-farm silages, most microbial deterioration is invisible initially and may only be de-

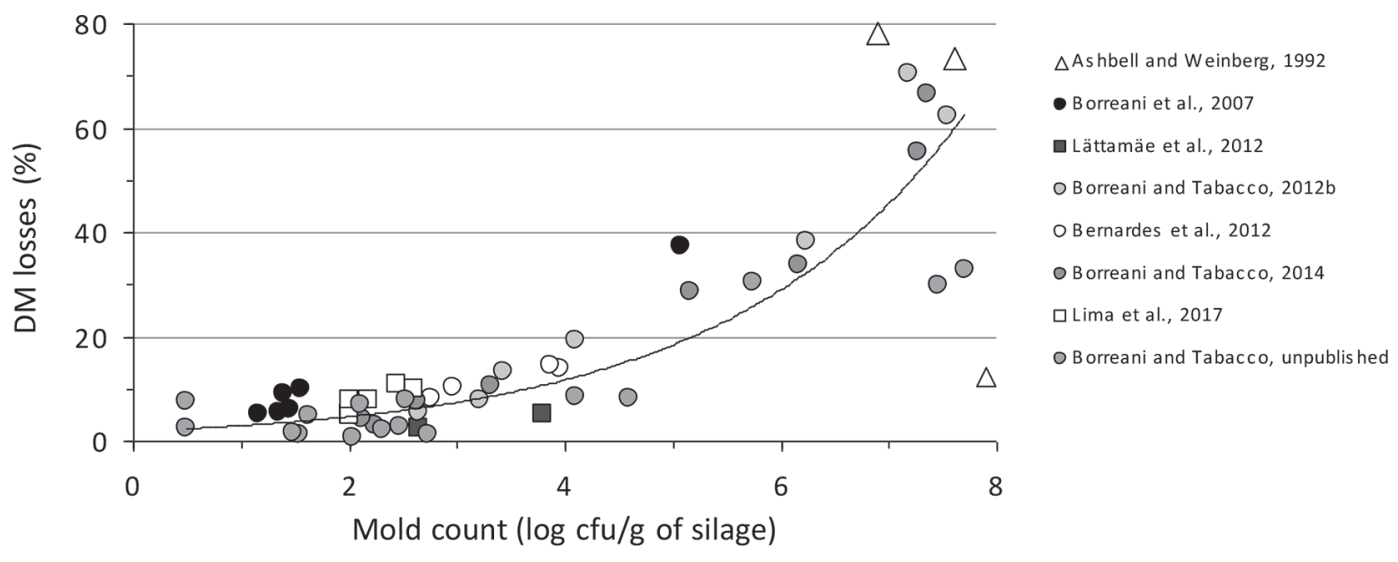

Figure 3. Silage DM losses in farm bunker silos determined with the buried bags technique and their correlation with the mold count. Regression equation: DM losses $(\mathrm{g} / \mathrm{kg})=13.95 \mathrm{MOLD} \_C O U N T^{2}-34.45 \mathrm{MOLD} \_$COUNT +63.22 , where mold count is expressed as log 10 cfu/g of silage; $\mathrm{R}^{2}=0.827$. Ashbell and Weinberg (1992), Borreani et al. (2007), Lättamäe et al. (2012), Borreani and Tabacco (2012b), Bernardes et al. (2012), Borreani and Tabacco (2014), Lima et al. (2017), and G. Borreani and E. Tabacco, University of Turin, Italy, unpublished. 


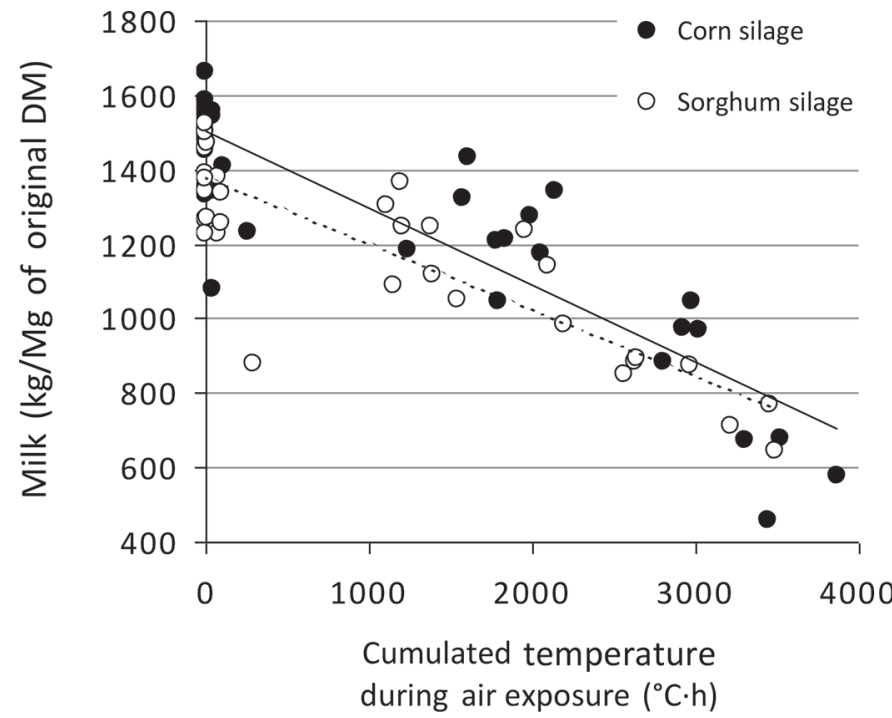

Figure 4. The estimated milk yield per $\mathrm{Mg}$ of pre-ensiled harvested $\mathrm{DM}$ of the corn and sorghum silages in relation to the hourly accumulated temperature rise $\left({ }^{\circ} \mathrm{C} \cdot \mathrm{h}\right)$ above the ambient temperature over $14 \mathrm{~d}$ of air exposure. Full symbols, corn silage; empty symbols, sorghum silage; full regression lines, corn silages; dotted regression lines, sorghum silages (from Tabacco et al., 2011b).

tected by a temperature rise in the forage (Muck and Holmes, 2000; Borreani and Tabacco, 2010). Each $8.3^{\circ} \mathrm{C}$ increase in temperature in 1 tonne of $30 \%$ DM silage requires over $26 \mathrm{MJ}$ (6.3 MCal) of energy (Richard Muck, USDA-ARS, Madison, WI, personal communication: assumes core temperature readings in a silage bunker or pile with minimal heat loss), costing around $4 \mathrm{~kg}$ in lost milk production per tonne of silage (Hoffman and Combs, 2009). In a controlled laboratory experiment on corn and sorghum silages, Tabacco et al. (2011b) observed an average loss of $10 \%$ of the estimated milk yield when aerobic spoilage computed as the sum of hourly differences between silage and air temperature reached approximately $1,000^{\circ} \mathrm{C} \cdot \mathrm{h}$ (Figure 4 ). In this experiment, an accumulated temperature-time rise of $1,000^{\circ} \mathrm{C} \cdot \mathrm{h}$ corresponded to about 2 to $3 \mathrm{~d}$ of silage heating, whereas mold began to be visible after an accumulated temperature-time rise of at least $1,400^{\circ} \mathrm{C} \cdot \mathrm{h}$. When silage temperature begins to increase due to the activity of aerobic microorganisms, nutritive values could decrease by as much as $16 \%$ before molds become visible.

In addition to the direct economic loss of DM and nutrients, spoiling or spoiled silage can also cause indirect losses, due to the lower nutritive value, reduced palatability, and the risk of negative effects on animal performance and health (Kung et al., 1998). Some of these effects are connected to the proliferation of potentially pathogenic or otherwise undesirable microorgan-

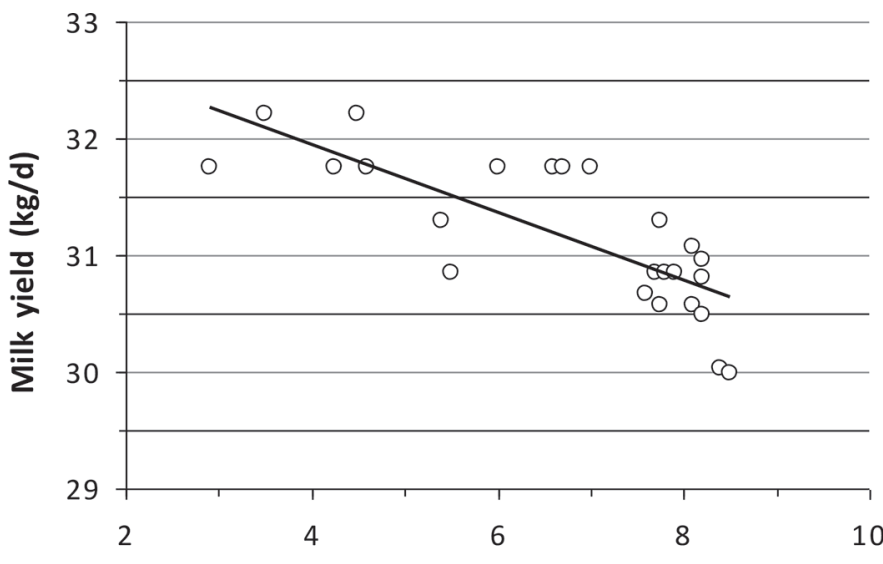

Yeast count (log cfu/g of silage)

Figure 5. Relationship between milk production and yeast count in aerobically unstable high-moisture corn (Hoffman and Ocker, 1997, modified).

isms (Lindgren et al., 2002; Driehuis, 2013; Spadaro et al., 2015) and mycotoxin synthesis (Korosteleva et al., 2007; Richard et al., 2009; Cavallarin et al., 2011; Ogunade et al., 2016).

In the last $20 \mathrm{yr}$, limited research has been done into the effects of feeding diets containing spoiling or spoiled silage. Hoffman and Ocker (1997) fed TMR containing aerobically stable and unstable high moisture shelled corn to mid-lactation cows for three 14-d periods. Although DMI was unaffected, the milk yield of the cows fed spoiling corn declined by approximately $3.2 \mathrm{~kg} /$ cow per day during each period compared with cows fed fresh, aerobically stable high-moisture corn (Figure $5)$. Whitlock et al. (2000) reported steers fed visibly spoiled corn silage at increasing rates $(0,25,50$, and $75 \%$ ) showed reduced DMI, from 8.0 to $6.7 \mathrm{~kg}$ per animal per day, and reduced $\mathrm{OM}$ and NDF digestibilities of 6.6 and $11.3 \%$, respectively.

More recently, Gerlach et al. (2013) reported an average $53 \%$ reduction in DMI of corn silages exposed to air for $8 \mathrm{~d}$ before being offered to goats in a preference trial. Silage temperature during aerobic exposure (expressed as difference to ambient temperature, $\Delta \mathrm{T}$ ) was the best predictor of DMI, intake being greatest in silages with the lowest $\Delta \mathrm{T}$ (Figure 6 ). The same authors reported aerobic exposure of alfalfa and grass silages also strongly influenced preference and short-time DMI by goats, although silage temperature and fermentation products changed only slightly during aerobic exposure (Gerlach et al., 2014a,b). Pooling data from these 3 experiments (Gerlach et al., 2013, 2014a,b), a negative relationship between mold count of the offered forage and DMI by goats can be observed (Figure 7). 


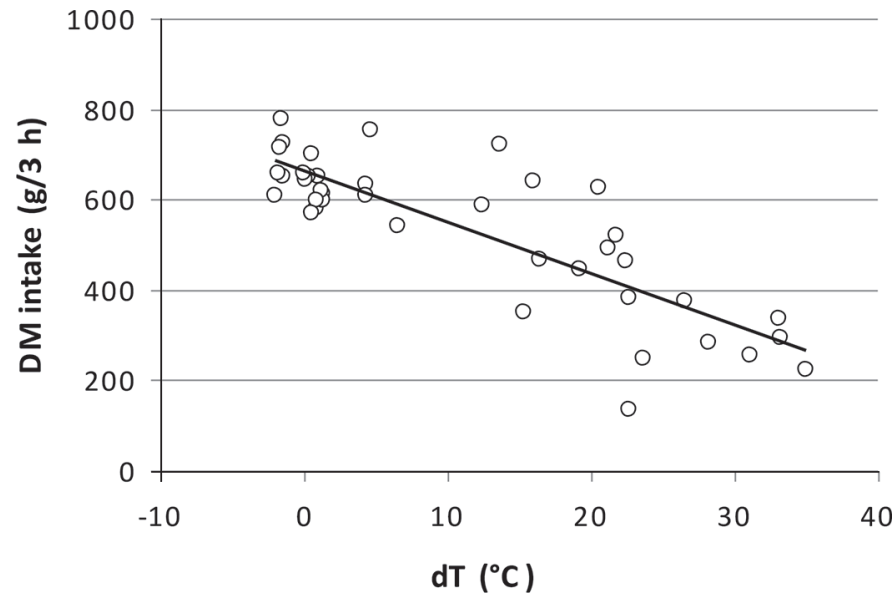

Figure 6. Relationship between DMI $(\mathrm{g} / 3 \mathrm{~h})$ of goats and corn silage temperature during aerobic exposure (expressed as the difference between silage and ambient temperature, dT; data from Gerlach et al., 2013, modified).

Windle and Kung (2013) evaluated the effect of feeding a fresh or aerobically spoiling silage-based TMR on intake and rumen fermentation parameters in heifers. The TMR exposed to air had a greater $\mathrm{pH}$, more yeasts, and lower concentrations of lactic acid, acetic acid, and ethanol than fresh TMR, and had temperatures 5 to $30^{\circ} \mathrm{C}$ above ambient $\left(20-22^{\circ} \mathrm{C}\right)$ temperatures. Feeding spoiled TMR alone resulted in a lower DMI, and more yeasts in rumen fluid than heifers fed fresh TMR. However, they did not find any differences among treatments in ruminal VFA.

Salvo et al. (2015) found feeding silages exposed to air for $48 \mathrm{~h}$ or inoculated with Pichia norvegensis, a lactate-assimilating yeast species found in corn silages

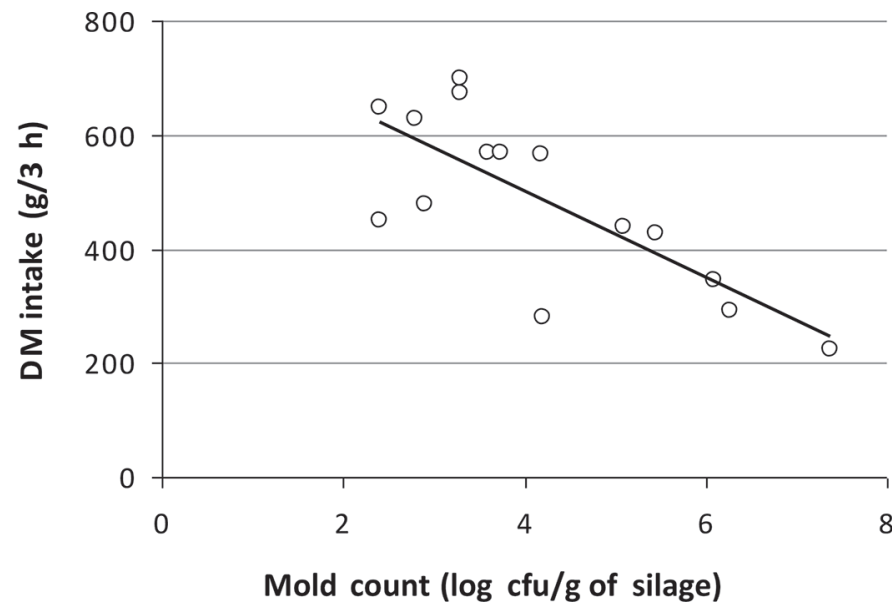

Figure 7. Relationship between DMI $(\mathrm{g} / 3 \mathrm{~h})$ of goats and mold count of silage during aerobic exposure (data from Gerlach et al., 2013, 2014a,b). in Brazil, at $1 \times 10^{5} \mathrm{cfu} / \mathrm{g}$ did not alter feed intake, but decreased $3.5 \%$ FCM production by 1.38 and $1.27 \mathrm{~kg} / \mathrm{d}$, and feed efficiency by 5.7 and $8.5 \%$, respectively, compared with the control treatment. Santos et al. (2015) reported the addition of Issatchenkia orientalis, a spoilage yeast commonly found in fermented silage, when added to a TMR at high levels, has the potential to reduce in vitro NDF digestion and alter other aspects of ruminal fermentation compared with the control treatment.

\section{MEASUREMENT OF LOSSES IN FARM-SCALE SILAGE}

The first step for farmers to improve efficiency in their silage making systems is to know actual DM losses. Several methods have been proposed to determine and model DM losses under controlled conditions (i.e., Honig, 1990; Ashbell et al., 1991), but such methods may not be relevant for estimating losses under farm conditions (Ashbell and Lisker, 1988).

Three methods are available to measure losses at farm scale: (1) weighing method: total-in versus totalout DM mass flow of the silo (Köhler et al., 2013); (2) buried bag method: recovering at feed-out weighed bags filled with silage at harvesting and placed in different parts of the silo (Ashbell and Lisker, 1988; Borreani et al., 2007); and (3) ash method: sampling silage at silo filling and at feed-out phase and analyzing for ash content or other nondegradable components (e.g., nalkanes; Dickerson et al., 1991; Ashbell and Weinberg, 1992).

Köhler et al. (2013) proposed a standardized method to determine DM losses through mass flow of forage during ensiling, using a total-in versus total-out procedure: the principle behind the measurements from harvesting to feeding is shown in Figure 8. During harvest, every wagonload was weighed with a measurement accuracy of $\pm 10 \mathrm{~kg}$ and 4 samples per hectare were retrieved from the harvested forages. During the period of removal, all silage was taken out of the silos by a mixer wagon equipped with a digital weighing system, and DM content was determined weekly by 3 core samples taken from the silo face at different heights. The DM loss was calculated by subtracting the total DM mass fed from the total ensiled DM mass. Spoiled materials, which were not used for feeding, were regarded as losses (Köhler et al., 2013). This method was used successfully by Borreani and Tabacco (2014) to calculate the economic benefits of applying a novel OB plastic film to cover corn bunker silos.

The buried bag method was first proposed by Allred et al. (1955) and refined by McGuffey and Owens 
(1979), and based on using woven polypropylene (or nylon) mesh bags filled with well-mixed fresh material (from 3 to $7 \mathrm{~kg}$ of fresh weight/bag), weighed, and buried in different parts of the silo. The bags should have the capacity to contain all the weighed forage particles, but at the same time permit gas and fluid exchanges with the surrounding silage. To help recover the bags during unloading, a cotton white tape (2 to $4 \mathrm{~cm}$ wide) is attached and laid out in the expected direction of the feed-out face for about $50 \mathrm{~cm}$ (Borreani et al., 2007). The bag locations (replications in 3 to $n$ sections spaced 5 to $10 \mathrm{~m}$ apart) in the silo should represent the variations in tendency to aerobic deterioration of the different parts of the silo and should at least be representative both of the central part of the silo (core) and of the peripheral 0.40 to $0.50 \mathrm{~m}$ of the stored silage surfaces. Peripheral bags should be placed at least at 2 distances from the bunker walls (close: from 0 to $1.5 \mathrm{~m}$ from the silo wall; far: from 1.5 to $3.0 \mathrm{~m}$ from the silo wall; Borreani and Tabacco, 2014). The bags are recovered at feed-out, cleaned of attached particles, weighed, and sub-sampled for DM, and fermentative and microbial analyses. This method better represented DM losses in farm-scale silages compared with the all-in minus all-out method, and it was better for comparing different covering or weighting methods (Borreani et al., 2007; Bernardes et al., 2012; Borreani and Tabacco, 2014) because losses near the cover can be specifically measured.

Measuring ash is an indirect method to estimate losses based on the assumption that as spoilage occurs, OM disappears but the absolute amount of ash remains constant (Ashbell and Weinberg, 1992). The validity of the estimation of the DM losses is mainly dependent on the accuracy and representativeness of the sampling.
Regardless of herbage ash content at ensiling or in the silage core, small increases in ash content of deteriorated silage represent large percentage unit increases in DM loss as can be seen when using the equation for calculating DM losses by ash content:

$$
\mathrm{DM} \operatorname{loss}(\%)=\left[1-\left(\operatorname{ash}_{\text {fresh }} / \mathrm{ash}_{\text {silage }}\right)\right] \times 100
$$

where $\operatorname{ash}_{\text {fresh }}=$ ash content of the crop at ensiling; and $\mathrm{ash}_{\text {silage }}=$ ash content of the silage at removal from the silo.

It is also suggested that this method could be used to estimate OM losses due to spoilage, when herbage ash content at ensiling is unknown, by comparing ash in the spoiled samples (top surface sample) to that from a well-preserved reference sample (core sample). The relationship between ash in a silage sample and spoilage loss of OM can be expressed as

$$
\begin{gathered}
\text { spoilage loss }(\% \mathrm{OM})=[1-(\mathrm{AF} \times \mathrm{OMS}) / \\
(\mathrm{AS} \times \mathrm{OMF})] \times 100
\end{gathered}
$$

where $\mathrm{AF}=$ percent ash at the face, $\mathrm{OMF}=$ percent organic matter at the face, $\mathrm{AS}=$ percent ash in the top sample, and OMS = percent organic matter in the top sample (Ashbell and Weinberg, 1992).

\section{MANAGEMENT STRATEGIES TO REDUCE AEROBIC DETERIORATION OF SILAGE}

The most important factors influencing the preservation efficiency of forage during ensiling are the degree of anaerobiosis reached in the filled silo and its maintenance over the entire conservation period (Woolford,

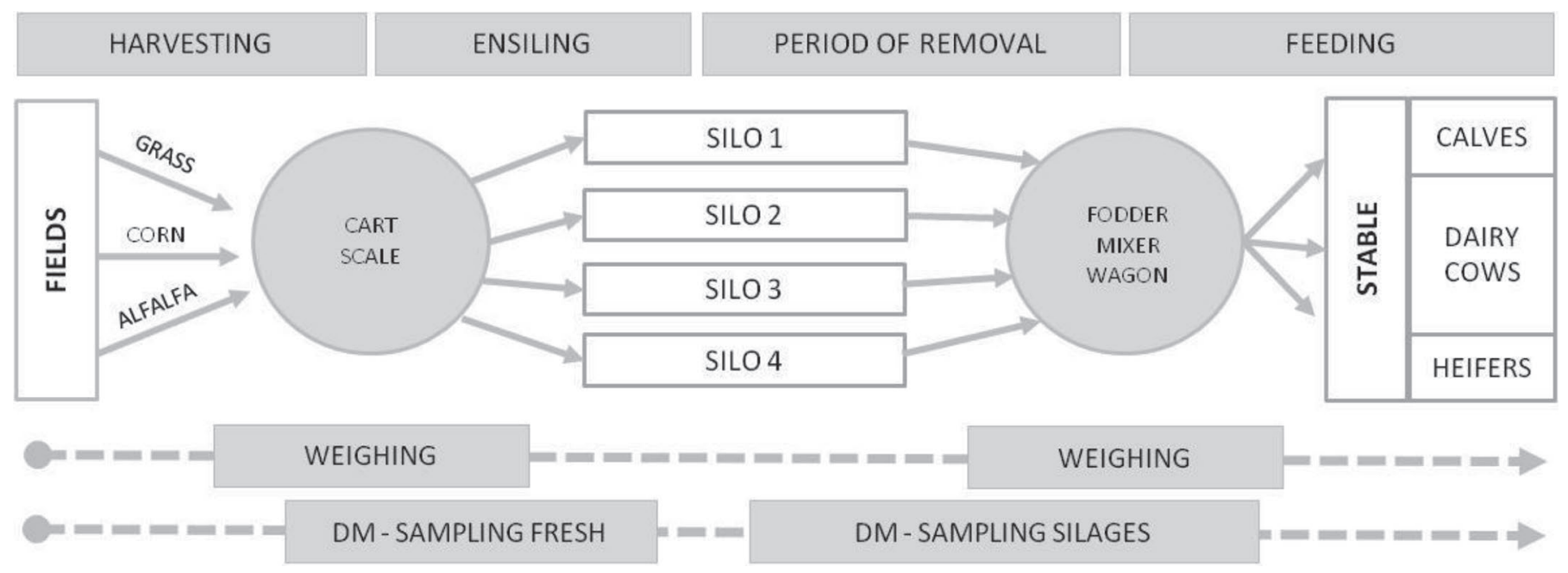

Figure 8. Principle of measurements used for the total-in versus total-out method (adapted from Köhler et al., 2013). 
1990; Borreani et al., 2007). Several factors affect silage $\mathrm{DM}$ and nutritional losses during conservation and feed-out, such as the daily feed-out rate (Mahanna and Chase, 2003), the use of silage additives and the fermentation profile (Weinberg and Muck, 1996), the method of sealing and type of plastic sealing (Savoie, 1988; Borreani et al., 2007), DM content at ensiling, particle size, filling rate, and the packed density of silage in the silo (Johnson et al., 2002; Holmes and Muck, 2007). The importance of a uniform, high-quality silage over the whole profile of the silo has recently been pointed out by several researchers (Muck, 2013; Wilkinson and Davies, 2013). Good microbiological quality throughout the whole silo mass can be obtained by increasing the silage density through proper compaction during silo filling (Muck and Holmes, 2000); by planning the silo size to achieve the correct daily feed-out rate, which depends on the season and latitude (Borreani and Tabacco, 2012a); by properly sealing and covering the silo to minimize oxygen penetration during the conservation phase (Borreani et al., 2007; Bernardes et al., 2012); by using an additive to increase aerobic stability of the silage (Kristensen et al., 2010; Tabacco et al., 2011a); by weighing down the cover effectively to hold it tightly in place and to maintain contact between the plastic film and the silage (McDonnell and Kung, 2006); by sealing joints in the plastic film; by lining bunker walls (Lima et al., 2017); and by reducing the risk of mechanical damage to the cover by protecting it with a net or tarpaulin (Wilkinson and Davies, 2013).

\section{Packing to Improve Silage Density}

Prior to the fermentation phase, oxygen within the voids around forage particles allows plant enzymes and aerobic microorganisms to respire, using readily available carbohydrates and contributing to DM loss. Higher void volume or porosity results in a larger reservoir of oxygen. When silage is exposed to oxygen (air), the rate of oxygen movement through the silage is proportional to the porosity of the silage (Pitt and Muck, 1993). This oxygen allows aerobic microorganisms to consume readily available carbohydrates and acids within the silage, causing DM loss. Situations where surfaces are exposed to oxygen include: (1) filling surface when forage is not being added to the storage; (2) top surface through the cover (permeable cover, holes in cover, joints in cover, and so on); (3) bunker walls, especially if not lined and have cracks; and (4) feed-out face.

Porosity is defined as the volume of gas-filled voids as a fraction of total silage volume. Pitt and Muck (1993) indicated porosity was a function of silage density:

$$
\Phi=1-\left(\rho / \rho_{\max }\right),
$$

where $\Phi=$ porosity (fractional); $\rho=$ material density; and $\rho_{\max }=$ maximum material density when all voids are removed.

Whereas Pitt and Muck (1993) calculated $\rho_{\max }$ based solely on the DM content of the crop, Richard et al. (2004) accounted for differences in porosity due to the ash and OM contents, so porosity was calculated as

$$
\begin{gathered}
\Phi=1-\rho_{\mathrm{wb}} \times\left\{\left[(1-\mathrm{DM}) / \rho_{\mathrm{w}}\right]+\left[(\mathrm{DM} \times \mathrm{OM}) / \rho_{\mathrm{om}}\right]\right. \\
\left.+\left[(\mathrm{DM} \times(1-\mathrm{OM})) / \rho_{\text {ash }}\right]\right\},
\end{gathered}
$$

where $\rho_{\mathrm{wb}}=$ material density wet basis $\left(\mathrm{g} / \mathrm{cm}^{3}\right) ; \rho_{\mathrm{w}}=$ density of water $\left(1 \mathrm{~g} / \mathrm{cm}^{3}\right) ; \rho_{\mathrm{om}}=$ density of organic matter $\left(1.6 \mathrm{~g} / \mathrm{cm}^{3}\right) ; \rho_{\text {ash }}=$ density of ash $\left(2.5 \mathrm{~g} / \mathrm{cm}^{3}\right)$; $\mathrm{DM}=$ dry matter content (fractional); and $\mathrm{OM}=$ organic matter content (fractional).

From Figure 9, it is apparent that porosity decreases with increased bulk density. If DM loss is to be minimized, porosity should be minimized, and this is accomplished by increasing bulk density and limiting DM content to the optimal range of 0.3 to $0.4 \mathrm{~g} / \mathrm{g}$. Holmes and Muck (2007) recommend a minimum average bulk density of $705 \mathrm{~kg} / \mathrm{m}^{3}$ for bunker and pile silos to limit porosity to a maximum of 0.4 . This can be determined by the mass ensiled divided by the volume of crop in the silo.

If the above theory is correct, DM losses should decrease as silage density is increased. When studying 19 bunker silos after an average 96-d storage period, Ruppel (1992) found a relationship for DM loss as a function of density. His average rate of DM loss was $2.5 \%$ per month. Holmes (2006) converted the Ruppel DM loss values to a loss per day value and then multiplied by $180 \mathrm{~d}$ to generate a relationship of DM loss for a 180-d period based on DM density. The expression is

$$
\begin{gathered}
\text { DM loss }(\%)=29.1-0.058 \\
\times \text { DM density }\left(\mathrm{kg} \text { of } \mathrm{DM} / \mathrm{m}^{3}\right) .
\end{gathered}
$$

Ruppel et al. (1995) found "Packing intensities >0.64 htonne per tonne were associated with higher silage densities, lower losses, and greater aerobic stability." Later, Ruppel (1997) recommended a minimum factor of 0.4 $\mathrm{h} \cdot \mathrm{t} / \mathrm{t}(800 \mathrm{~h} \cdot \mathrm{lbs} . / \mathrm{T})$ to ensure adequate silage packing. They found a low correlation between DM density and DM loss; however, the relationship was explained as, "The DM loss was reduced by 2.2 percentage points for every increase of $50 \mathrm{~kg} / \mathrm{m}^{3}$ in density, which was associated with more intensive packing." Inserting 50 $\mathrm{kg} / \mathrm{m}^{3}$ into the DM density component of Equation [5], 


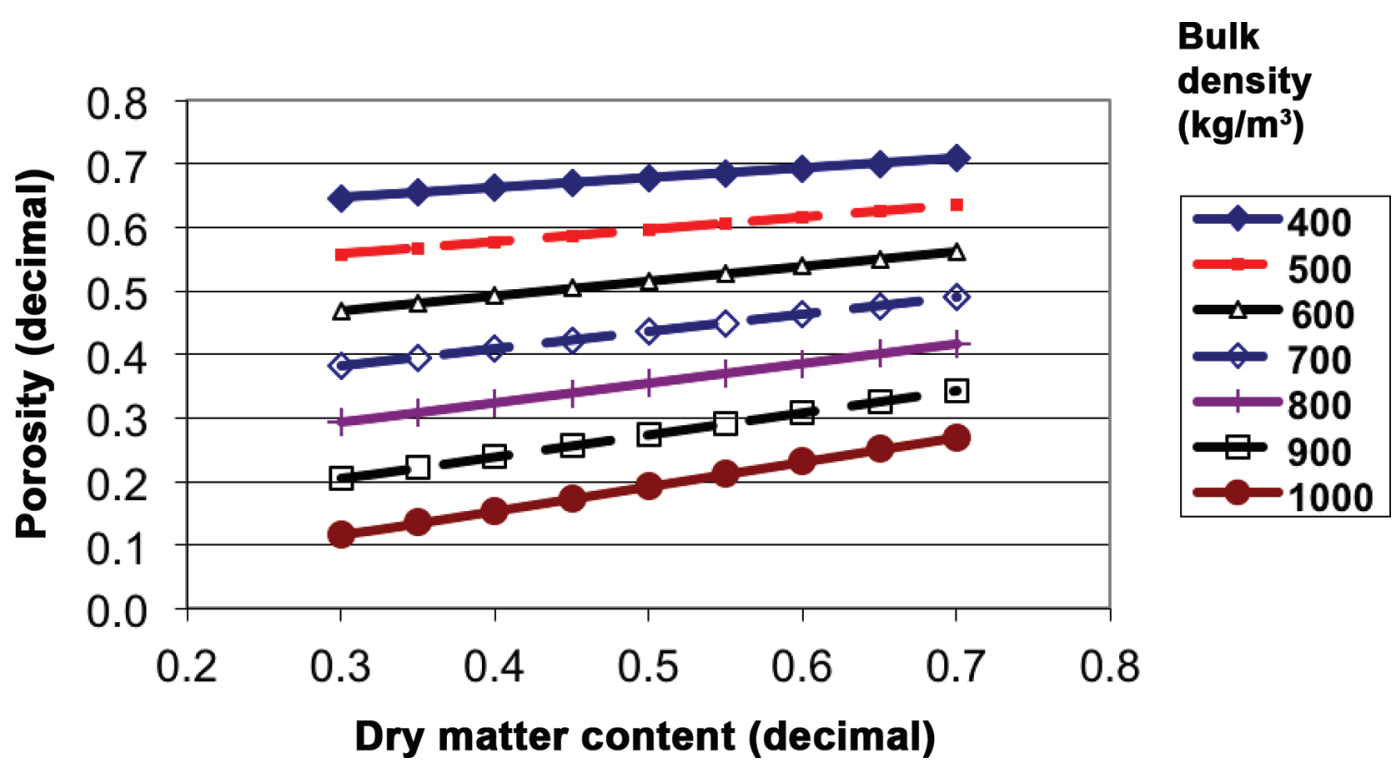

Figure 9. Porosity as a function of DM content and bulk density of silage with a $5 \%$ ash content using Equation [4] (from Richard et al., 2004). Color version available online.

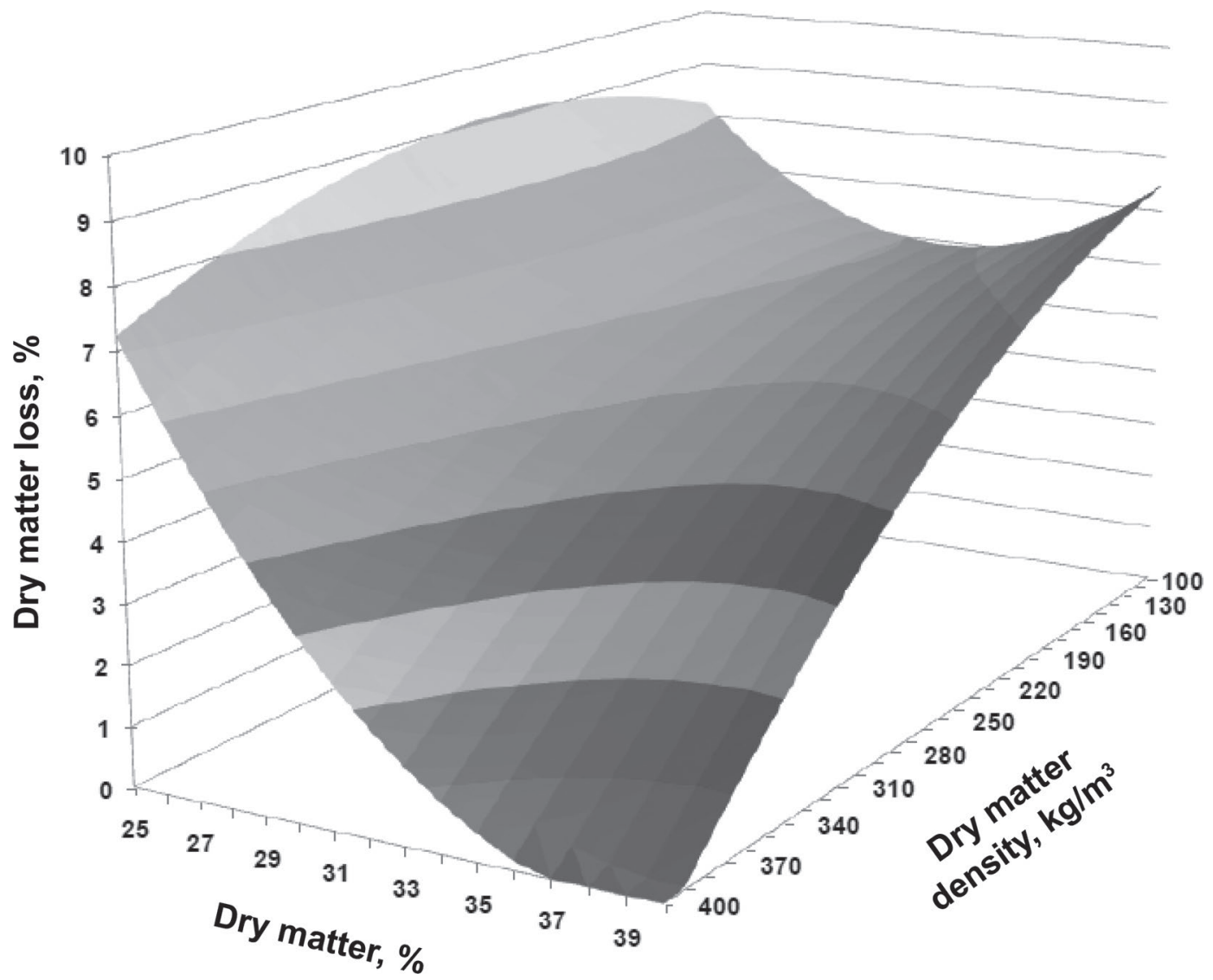

Figure 10. Predicted response surface regression of DM density $\left(\mathrm{kg}\right.$ of $\left.\mathrm{DM} / \mathrm{m}^{3}\right)$ and $\mathrm{DM}$ content (\%) versus DM losses (\%) in corn silage from a bunker silo (from Griswold et al., 2010). 
Table 3. Dry matter loss and correlation coefficients for density and feed-out rate (data from Köhler et al., 2013)

\begin{tabular}{lcccc}
\hline Forage & $\begin{array}{c}\text { DM loss } \\
\text { range }(\%)\end{array}$ & $\begin{array}{c}\text { Average DM } \\
\text { loss }(\%)\end{array}$ & $\begin{array}{c}\text { Density correlation } \\
\text { coefficient }\end{array}$ & $\begin{array}{c}\text { Feed-out rate } \\
\text { correlation coefficient }\end{array}$ \\
\hline Grass & -2 to 26 & 9 & -0.039 & -0.570 \\
Corn & -4 to 19 & 10 & -0.625 & -0.555 \\
Alfalfa & 6 to 15 & 12 & - & - \\
\hline
\end{tabular}

the rate of loss becomes $2.9 \%$, higher than the $2.2 \%$ of Ruppel at al. (1995) due to the longer assumed storage period. Griswold et al. (2009) noted a weak $\left(\mathrm{R}^{2}=0.18\right)$ inverse relationship of DM loss with silage DM density. When they regressed DM loss against DM content and DM density, the correlation improved somewhat $\left(\mathrm{R}^{2}=\right.$ 0.28 ) and resulted in a nonlinear relationship (Figure 10; Griswold et al., 2010).

Köhler et al. (2013) studied DM losses using a total DM in versus a total DM out method in 48 bunker silos. They found DM losses and correlation coefficients for density and feed-out rate (Table 3). Dry matter loss was inversely and significantly related to density and feed-out rate for corn but was only related to feed-out rate for grass.

Robinson et al. (2016) studied 6 large silage piles filled with mature (3) and immature (3) cereal crops. Toward the bottom of the piles (1.5 $\mathrm{m}$ from the floor), the bulk density was just below the recommended bulk density of $705 \mathrm{~kg} / \mathrm{m}^{3}$. The immature crop was slightly wetter than recommended. Dry matter loss was corrected for volatile compound evaporation during normal oven drying to produce a corrected DM loss. The fermentation and storage loss was estimated by the losses from Dacron bags placed in the silage mass. The feed-out face loss was determined from samples taken by face coring. The results of the study are summarized in Table 4. Total DM loss was slightly higher (9.7\%) for immature silage versus $4.5 \%$ for mature silage.

Brüning et al. (2018), studying the effects of compaction, delayed sealing, and aerobic exposure after ensiling on corn silage quality, found that delaying sealing promoted the formation of ethyl esters at silo opening. A 4-d delay in sealing resulted in the lowest aerobic

Table 4. Losses in large cereal crop silage piles (from Robinson et al., 2016)

\begin{tabular}{lcc}
\hline Crop maturity & Immature & Mature \\
\hline Bulk density $\left(\mathrm{kg} / \mathrm{m}^{3}\right)$ & 688 & 608 \\
DM (\%) & 28.9 & 39.1 \\
Volatiles-corrected DM loss & 5.3 & \\
Retrieved bags (\%) & 4.4 & 1.4 \\
Feed-out face (\%) & 9.7 & 4.1 \\
Total (\%) & 4.5 \\
\hline
\end{tabular}

stability compared with immediately and a 2-d delay in sealing. They concluded that corn silage quality is adversely affected by low compaction and delayed sealing.

Overall, these studies show a negative correlation between DM density and DM losses, but the relationship is not as strong as some might expect. However, this should not be a surprise. From Equation [4], porosity varies considerably for a given DM density with DM content (Figure 11). One would expect a much stronger relationship between bulk density and DM losses because porosity at a given bulk density varies far less with DM content (Figure 9).

High bulk densities are achieved by different means depending on the silo type. Gravity is used to pack forage in tower silos. The weight of material above compresses the material below. A gradual decrease in density occurs as measured from the bottom of the silo. The rate of decline in density increases in the top $6 \mathrm{~m}$ of a tower silo (Pitt, 1983). Wall friction affects density, so wider silos and smoother walls produce higher densities.

Most bunker and pile silos are less than $6 \mathrm{~m}$ high, so active physical compaction is needed to achieve bulk densities of greater than $705 \mathrm{~kg} / \mathrm{m}^{3}$. Honig (1991) reviewed European guidelines for packing silos and found

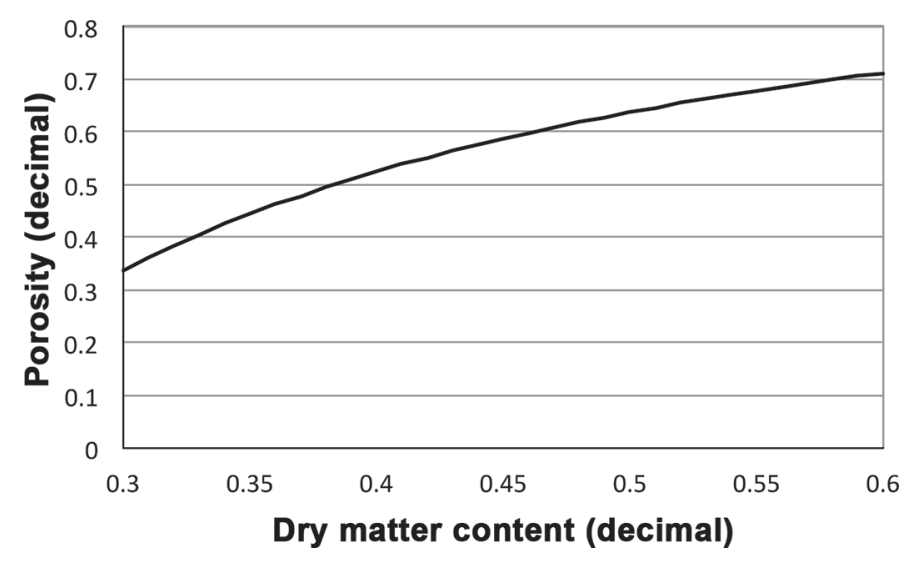

Figure 11. Porosity of silage packed to constant DM density (225 $\mathrm{kg}$ of DM $/ \mathrm{m}^{3}$ ) as a function of DM content based on Equation [4] assuming an ash content of 5\% DM (adapted from Holmes and Muck, 2009). 
most were more or less empirical and based on tractor weight/t of $\mathrm{DM}$ per $\mathrm{h}$ or compressions/t of $\mathrm{DM}$, or packing time/t of DM. Honig's summary of Laue (1990) indicated increased tractor weight increased density, and dual wheels reduced density in model bunker silos, whereas speed had no effect on density. Ruppel et al. (1995) surveyed 30 bunker silos filled with hay crop silages. The most important factors correlated with DM density were packing time per unit surface area and tractor weight. Muck and Holmes (2000) surveyed 168 bunker silos, approximately half corn silage and half alfalfa silage. Dry matter densities were correlated most strongly with how thinly loads of forage were spread in the silo, tractor weight, packing time/t as fed, and DM content. Use of single- or dual-wheeled packing tractors had no effect on density. Subsequent pilot-scale and field trials have confirmed the importance of tractor weight and to a lesser degree packing time/t (Muck et al., 2004a,b; Savoie et al., 2004). Converting these results to bulk density, factors having a positive effect on silage bulk density include (1) increasing total packing equipment weight; (2) increasing time spent packing per tonne of silage; and (3) increasing height of silage mass. Factors having a negative effect on silage bulk density include (1) increasing silage delivery rate to the silo; and (2) increasing DM content. Visser (2005) found bunker silos had greater DM density than silage piles for both alfalfa and corn silage. Corn silage DM density was lower than alfalfa silage density in both bunker and pile silos. This later finding was likely the result of a higher forage delivery rate for corn silage compared with alfalfa while packing procedure remained the same.

Several tools have been developed to help farmers improve silage density. Ruppel et al. (1995) reported DM density $\left(\mathrm{kg} / \mathrm{m}^{3}\right)$ increased linearly [slope of $83.6 \mathrm{~kg}$ / $(\mathrm{m}-\mathrm{h}-\mathrm{t})]$ with packing time/surface area $\left(\mathrm{h} / \mathrm{m}^{2}\right)$ multiplied by packing tractor weight (t). Holmes and Muck (2011a,b) have incorporated the relationships from Muck and Holmes (2000) into spreadsheets that can be used before filling a bunker or pile silo, respectively, to estimate the expected density to be achieved after filling and fermentation. These spreadsheets can be used to try "what if" scenarios to determine what practices need to be changed to achieve the desired density.

Measurement of densities in farm-scale bunker or pile silos is not without difficulties. Currently there are no known accurate means of measuring density during the filling process. The standard procedure for measuring density at feed-out is to force a probe into the feed-out face in a pattern to represent segments of the face. The probe captures the silage sample. The sample is forced from the probe and tested for weight and optionally DM content. The depth of the hole left in the feed-out face is measured and combined with the diameter of the probe to calculate the volume of sample. Because the probe holes are such a small portion of the silo feed-out face and because density decreases with height from the floor and proximity to walls and top surface (Craig and Roth, 2005; Visser, 2005; Craig et al., 2009), the chance for error is significant, and the procedure for sampling the feed-out face with a probe is time consuming and dangerous. Silage avalanches have occurred, engulfing workers and causing injury and death. Working to probe a silo face places people in the avalanche zone at risk. Another way to measure an average silage density is to weigh a quantity of silage removed from the silo, then measure the volume of the removed silage. The density is the weight removed divided by the volume. Holmes (2005) has developed a spreadsheet to estimate the density based on common shapes of silo faces. Norell et al. (2013) conducted tests to compare the bunker silo/silage pile density calculators (Holmes and Muck, 2011a,b), the weight by volume method, and the probing method to determine the accuracy of each. Their conclusion was, "Core sampling is recommended for directly assessing silage density, and the calculator method is recommended for estimating average density and for evaluating alternative management strategies during the silo filling and packing process. The feedout method performed poorly and is not recommended unless the storage structure has uniform silage face and easy-to-measure movements in the silage face."

\section{Silage Additives}

Lactate-utilizing yeasts are the primary microorganisms responsible for initiating aerobic deterioration in most silages (Pahlow et al., 2003). They grow at low $\mathrm{pH}$ using the strongest acid from LAB fermentation so silage $\mathrm{pH}$ increases as lactate decreases. Once silage $\mathrm{pH}$ has been raised sufficiently, other spoilage microorganisms become active. In corn silage, Acetobacter sp. may occasionally initiate deterioration (Spoelstra et al., 1988).

It is possible to delay aerobic deterioration when oxygen is present by inhibiting yeasts through the use of specific silage additives. The silage additives with the longest history of inhibiting yeasts and molds are organic acids or their salts (Kung et al., 2003). The most common acids are propionic, acetic, sorbic, and benzoic acids, although they are most widely used today as their salts to avoid their odors and corrosiveness. Buffered propionic acid contains ammonium propionate, sodium propionate, or calcium propionate, dependent on the source. Acetic acid is typically found in mixtures with buffered propionic acid to produce a less expensive additive. Potassium sorbate and sodium benzoate are 
the commonly used salts of sorbic acid and benzoic acid, respectively.

For these products to be effective, they must be applied at effective levels. For example, Kung et al. (2000) applied a buffered propionic acid to corn at ensiling at 1 to $3 \mathrm{~kg} /$ tonne of fresh weight. The highest application rate produced the greatest aerobic stability. The review of Kung et al. (2003) suggested buffered propionic acid products needed to be applied at 2 to $3 \mathrm{~kg} /$ tonne of fresh weight to consistently improve aerobic stability in corn silage.

Potassium sorbate and sodium benzoate have typically been used in the food industry and were considered too expensive for use in making silage until a few years ago. Recently in some countries, the cost of sodium benzoate has decreased, making it more competitive. These salts are in various silage additives as part of mixtures that may include propionates. A product containing potassium sorbate, sodium benzoate, and sodium nitrate was shown to improve aerobic stability in various crops (Knicky and Spörndly, 2011). Potassium sorbate is more effective than sodium benzoate at inhibiting yeasts (Auerbach and Nadeau, 2013; Bernardes et al., 2014). To compare additives with different levels of potassium sorbate and sodium benzoate, Auerbach and Nadeau (2013) assumed potassium sorbate was twice as effective as sodium benzoate, and aerobic stability in corn silage across trials was strongly positively correlated with the application rate expressed as sodium benzoate equivalents. Hafner et al. (2014) found that low levels of potassium sorbate $(91 \mathrm{mg} / \mathrm{kg}$ of fresh matter) increased yeast count. However, application of potassium sorbate at $1 \mathrm{~kg} /$ tonne of fresh matter was effective at reducing yeast count and improving aerobic stability in various trials (Teller et al., 2012; Bernardes et al., 2014; Hafner et al., 2014).

At the end of the 20th century, an inoculant (Lactobacillus buchneri) approach to improving aerobic stability reached the market. Lactobacillus buchneri is an obligate heterofermentative lactic acid bacterial species that can ferment lactic acid, producing acetic acid (Oude Elferink et al., 2001) as discussed earlier. The increased acetic acid in L. buchneri-treated silages is the presumed mechanism increasing aerobic stability. However, when Lactobacillus diolivorans is naturally present, its fermentation of the 1,2-propanediol produced by L. buchneri to propionic acid and 1-propanol (Krooneman et al., 2002) may produce exceptionally stable silage due to elevated propionic acid concentrations (e.g., Driehuis et al., 1999).

A meta-analysis of 43 laboratory-scale experiments evaluated the effectiveness of $L$. buchneri in improving aerobic stability in corn, grass, and small-grain silages (Kleinschmit and Kung, 2006). These authors found the aerobic stability response in corn silage was dose dependent $\left(25 \mathrm{~h}\right.$ to reach $2^{\circ} \mathrm{C}$ above ambient for untreated, $35 \mathrm{~h}$ for L. buchneri applied at $10^{5} \mathrm{cfu} / \mathrm{g}$ crop or less, $503 \mathrm{~h}$ for L. buchneri applied at greater than $10^{5}$ $\mathrm{cfu} / \mathrm{g})$. Yeast counts were lowest in corn silage treated with $L$. buchneri applied at $>10^{5} \mathrm{cfu} / \mathrm{g}$. In grass and small-grain silages, yeast counts were low across all 3 treatments, but aerobic stability increased with dose (206, 226, and $245 \mathrm{~h}$, respectively). Lactobacillus buchneri treatment reduced DM recovery by approximate 1 percentage point compared with untreated in all crops.

Lactobacillus buchneri has been effective in improving aerobic stability at field scale. Tabacco et al. (2011a) surveyed 42 farm silos containing corn silage, half treated with L. buchneri. Aerobic stability was negatively correlated with yeast count across all silages. The improved aerobic stability in inoculated silages appeared linked to a reduction in yeast count compared with untreated silages.

Most recently, combination inoculants have been introduced. These inoculants contain both L. buchneri and more traditional homofermentative strains. The goal is to have the homofermentative strains dominate early fermentation to achieve an efficient fermentation and a rapid reduction in silage $\mathrm{pH}$. After active fermentation, L. buchneri slowly converts some lactic acid to acetic acid. This concept was first investigated by Driehuis et al. (2001), inoculating perennial ryegrass with one of 4 treatments: untreated; L. buchneri alone; $L$. buchneri, L. plantarum, and P. pentosaceus; or $L$. plantarum and $P$. pentosaceus. The combination inoculant treatment had a similar fermentation to that of the homofermentative L. plantarum and P. pentosaceus treatment over the first $14 \mathrm{~d}$. At $90 \mathrm{~d}$, both the combination inoculant and L. buchneri alone had reduced yeast counts and increased aerobic stability compared with the untreated control.

More than 2 dozen peer-reviewed reports have been published using combination inoculants on various crops (Muck et al., 2017). In most of those studies, L. buchneri dominated the later stages of storage as evidenced by a decrease in lactic acid and increases in acetic acid and aerobic stability relative to those in untreated silage. Four papers report trials where the combination inoculant failed to improve aerobic stability. In Adesogan and Salawu (2004), 2 untreated pea/wheat mixtures naturally produced high acetic acid silages, and the combination inoculant failed to increase acetic acid concentration. Kang et al. (2009) found a combination inoculant improved aerobic stability in corn silage of one cultivar but not another. In Arriola et al. (2011), it appeared the untreated corn silage underwent a natural L. buchneri-like fermentation that the inoculant could not improve. Similarly in 
Thomas et al. (2013), the combination inoculant failed to produce a sorghum silage more heterofermentative than the corresponding untreated silage.

Overall, producers have alternatives that can aid in making silages more aerobically stable. The $L$. buchneri inoculants may be more cost effective than organic acids. However, there are several caveats. The current inoculants require a minimum of 45 to $60 \mathrm{~d}$ storage before substantial benefits to aerobic stability are observed, making them a poor choice in those circumstances where a silage is fed after a short storage period. Inoculants will not always succeed as indicated above, mostly due to variable levels of competition from the epiphytic population on the crop. Theoretically, chemical additives should provide more consistent effects (Kleinschmit et al., 2005). However, those effects are dependent upon application rates at or above those recommended on the product label as indicated by Kung et al. (2003). Because of cost, producers may be tempted to skimp on chemical additive rates, which can jeopardize the product effectiveness.

Finally, it is important to understand these additives inhibit yeast activity but rarely prevent it. Thus these additives must be used in concert with other good management practices to be successful.

\section{Plastic Cover}

The introduction of plastic films to cover silage in the early 1950s can be considered a revolution, as their use has allowed all farmers to benefit from the advantages of ensiling (Anonymous, 1953). Polyethylene was chosen because of its suitable mechanical characteristics and low costs, and because of its ability to create anaerobic conditions in the ensiled mass. In a 1,000-tonne horizontal silo (12 m wide, $32 \mathrm{~m}$ long, and $3.7 \mathrm{~m}$ high), more than $25 \%$ of the initial mass is within the top meter of the silage mass. Leaving the silage uncovered results in an average 47 and $11 \%$ total loss of OM in the upper $0.5 \mathrm{~m}$ and in the next $0.5 \mathrm{~m}$ below, respectively, while covering with low-density polyethylene (LDPE) film reduced these losses to 20 and $5 \%$, respectively (Bolsen, 1997). In farm corn silages, DM losses in the 0.9-m layer immediately below the PE plastic film can exceed $30 \%$ of the original ensiled crop, especially in the summer season (Borreani et al., 2007; Holmes and Bolsen, 2009). The quality of the plastic film becomes a key factor because silages are stored in farm silos for periods of 12 mo or more. The main characteristics of an ideal film to cover silage should be high mechanical strength properties (puncture resistance and tear resistance) to resist handling, wind, hail, animals, and frost; low permeability to oxygen; and UV resistance. These properties need to be maintained over a long period (more than 1 yr) in a natural rain-, hail-, snow-, frost-, and sun-exposed environment.

Pitt (1986), who calculated the DM losses due to oxygen infiltration in silage, suggested the plastic film used to cover silage played a role in silage oxygen infiltration, due to the relatively high oxygen permeability of LDPE films (permeance to $\mathrm{O}_{2} 178,000 \mathrm{~cm}^{3} \mu \mathrm{m} / \mathrm{m}^{2}$ per $24 \mathrm{~h}$ ). Until the 2000 s, the only way of reducing film permeability to oxygen has been to increase the thickness of the films. Savoie (1988) calculated DM losses due to LDPE film permeability in relation to film thickness, and reported losses of 24.4 to $3.2 \mathrm{~g} / \mathrm{kg}$ of DM per 30-d storage period as film thickness increased from 25 to $200 \mu \mathrm{m}$. Lindgren et al. (1985) reported a 100$\mu \mathrm{m}$ LDPE cover was unable to prevent the diffusion of oxygen in peripheral areas of bunker-stored silages, leading to the growth of lactate-utilizing yeasts. Since the late-1950s to 2005, bunker silos have usually been covered using 110- to $200-\mu$ m-thick LDPE films. In the mid-1990s, multilayer co-extrusion blowing technologies became available allowing the production of plastic films using OB polymers in combination with LDPE. This allowed oxygen permeability to be reduced to values that can only be achieved by LDPE films thicker than 2,000 $\mu \mathrm{m}$ (Borreani and Tabacco, 2017). Because the co-extrusion of multilayer films helps to combine all the properties required for a specific application in one material, cover technology is changing rapidly, and new developments in sealing strategies have recently been reported (Borreani and Tabacco, 2017). Resins that can be coextruded with $\mathrm{PE}$ and which improve film impermeability to gasses $\left(\mathrm{O}_{2}, \mathrm{CO}_{2}\right)$ include polyamides $(\mathbf{P A}$; permeance to $\mathrm{O}_{2}$ for nylon- $6,1,500 \mathrm{~cm}^{3} \mu \mathrm{m} / \mathrm{m}^{2}$ per 24 h) and ethylene-vinyl alcohol copolymer (EVOH; 4 to $24 \mathrm{~cm}^{3} \mu \mathrm{m} / \mathrm{m}^{2}$ per $24 \mathrm{~h}$ ). These 2 groups of resins appear to be the most promising because a layer of just a few micrometers coextruded with PE is able to reduce the oxygen permeability of the resulting film by more than an order of magnitude compared with PE alone. Although the costs of the new films are around 50 to $60 \%$ higher than those of commercial PE films, the cost savings in farm applications from reduced DM losses and improved microbiological silage quality are greater than the extra film cost (Bolsen et al., 2012; Borreani and Tabacco, 2014; Wilkinson and Fenlon, 2014).

The results of several studies on the first OB film, using PA as the barrier polymer and formulated with both black and white PE in a $125-\mu$ m-thick film (OB 1 step) or as a transparent $45-\mu \mathrm{m}$-thick film covered with a second thicker PE film or net (OB 2 step) on grass and corn silages, have shown both positive and negligible effects on DM losses and visible top spoilage and are summarized in the review of Wilkinson and Fenlon (2014). The losses from the top surfaces of the 
bunker silo experiments are reported in Figure 12, and the length of each line shows the difference between the 2 films. The black lines indicate lower losses for the OB film and the gray lines the opposite. The analysis made by Wilkinson and Fenlon (2014) underscore the great variation in DM losses of silages stored in peripheral areas of horizontal silos, ranging from less than 50 to 700 $\mathrm{g} / \mathrm{kg}$ for LDPE films and from 50 to $370 \mathrm{~g} / \mathrm{kg}$ of silage for OB films. Only 2 out of 41 trials showed greater losses for OB films than for PE films. Although the data are quite variable, the frequency of large differences between the types of sealant films tends to increase as the overall level of loss increases. These first studies demonstrated the need to reduce oxygen permeability of plastic films below $100 \mathrm{~cm}^{3} / \mathrm{m}^{2}$ per $24 \mathrm{~h}$ (at standard conditions: $23^{\circ} \mathrm{C}, 0.1 \mathrm{MPa}$ and $85 \%$ relative humidity) to obtain a substantial reduction in DM losses when those films were used to cover Italian ryegrass (Wilkinson and Rimini, 2002) and maize silages (Borreani et al., 2007). When PA is used as a barrier polymer, a PA thickness of at least $14 \mu \mathrm{m}$ should be used in the co-extruded film to obtain an oxygen permeability below $100 \mathrm{~cm}^{3} / \mathrm{m}^{2}$ per $24 \mathrm{~h}$, which is about $90 \%$ lower than the values observed for the thicker, commercially available PE film. Borreani and Tabacco (2008) and Borreani et al. (2013) observed an improvement in aerobic stability when OB films were used, as they led to reductions in DM losses and aerobic and anaerobic spores of spoilage microorganisms in peripheral areas of the silo and during aerobic stability tests. This first generation of OB film showed good mechanical characteristics compared with commercial LDPE films of the same thickness, even though they appeared to be more rigid than LDPE films, especially when the thickness of the film was reduced to around $50 \mu \mathrm{m}$ (De Angelis, 2012). Some farm experiences with $45-\mu \mathrm{m}$-thick PE/ PA OB films reported problems of fragility of the film. This resulted in problems when the film was handled during silo covering operations and led to the necessity to protect the film, not only with a tarpaulin, but with another plastic film (2-step covering system) to avoid the risk of damage during conservation. Borreani et al. (2014) showed a positive interaction between the length of storage and the increased anaerobiosis of silage during conservation provided by an OB film compared with a PE film, reducing DM losses in the parts of the silo most at risk of spoilage.

In the first decade of the 2000s, several commercial farms throughout the world gathered evidence about the importance of coupling improved impermeability to oxygen with the mechanical performances of plastic films to cover horizontal silos, to minimize the risk of accidental damage to the cover (Borreani and Tabacco, 2017).

These promising first trials led to the next generation of high oxygen barrier films (HOB) made by coextruding a layer of a special grade of EVOH between 2 layers of LDPE (Borreani and Tabacco, 2012b). The

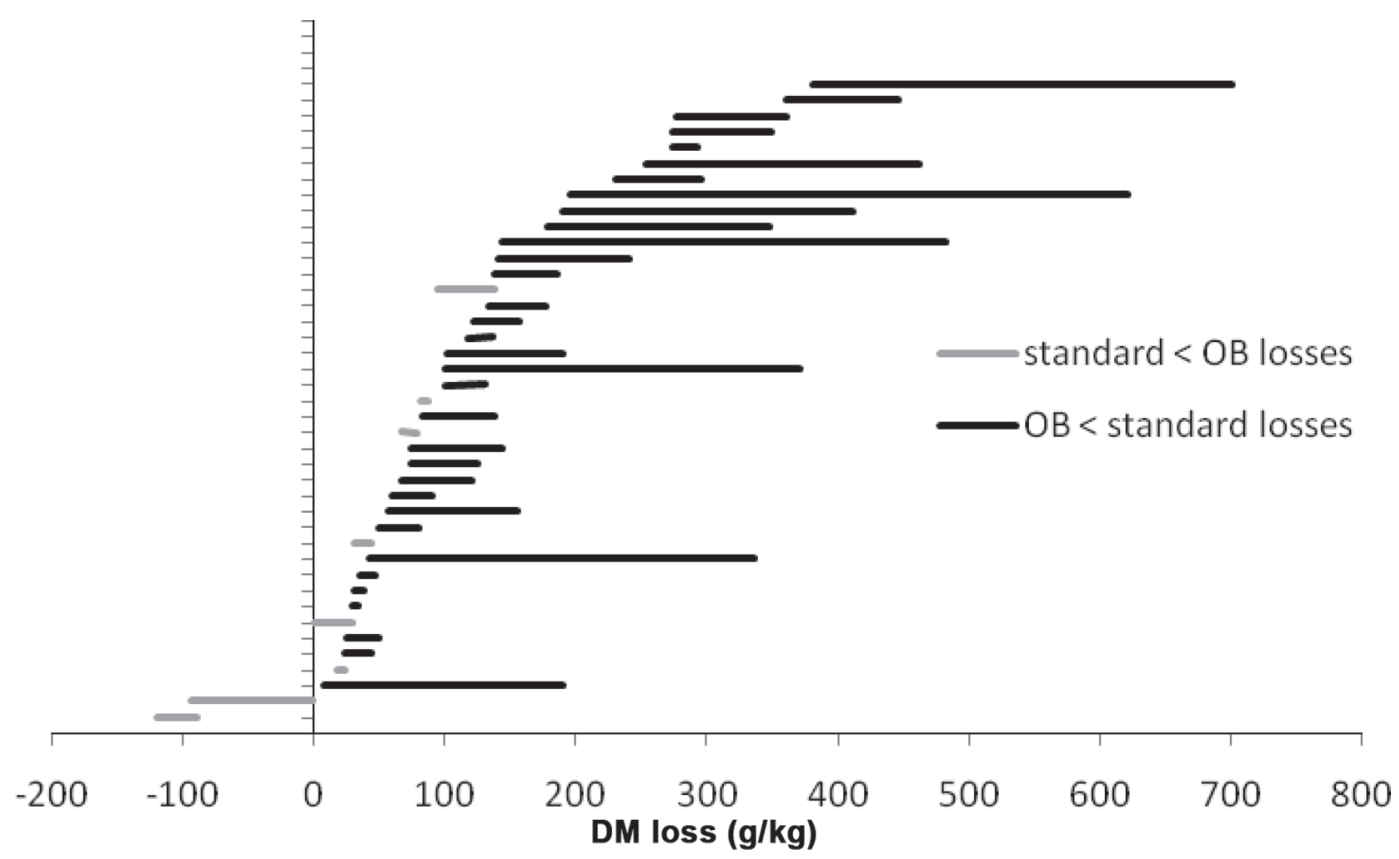

Figure 12. Horizontal silo comparison-differences [standard polyethylene (PE) vs. oxygen barrier (OB) film losses of DM] ordered by OB loss (from Wilkinson and Fenlon, 2014). 
EVOH layer improved the oxygen impermeability of the HOB film about 10-fold, and mechanical characteristics notably improved compared with the first generation of OB films (Borreani and Tabacco, 2014). This improvement was due to the new EVOH formula, which makes the film particularly soft at ambient temperature, and to the reduced thickness of the EVOH layer (from 2 to $3 \mu \mathrm{m}$; Borreani and Tabacco, 2014). Borreani and Tabacco (2014) reported a delay in the onset of aerobic deterioration in the silage under the HOB film, resulting in lower DM losses and a less spoiled silage that had to be discarded. This led to a net gain when a HOB film was used, due to the increased DM recovery and reduced labor required to clean the top layer daily, plus the safety benefit of spending less time removing spoiled feed next to the feed-out face. Furthermore, the additional benefit is lowering the risk of feeding "edible" silage (defined by visual judgment) with poor hygienic quality. The economic return at farm scale of using $\mathrm{HOB}$ film instead of commercial PE film ranged from $2.00 €$ (Borreani and Tabacco, 2014) to $4.50 €$ (Bolsen et al., 2012) for each tonne of fresh matter ensiled.

\section{Feed-Out (Unloading) Rates from the Silo}

In well-covered silages, the feed-out removal rate of silage from the silo face represents one of the most important factors to prevent aerobic spoilage (Honig et al., 1999; Borreani and Tabacco, 2012a). The greater the unloading rate, the lower the losses. Honig et al. (1999) showed weekly unloading rate and depth of air penetration greatly affected net energy losses from mediumsized silos with $35 \%$ DM silages (Table 5). Tabacco and Borreani (2002) presented farm-scale studies with deteriorating maize silages, underscoring the importance of coupling high feed-out rates with careful silo management to control aerobic deterioration. Holmes and Muck (2007) related DM losses and feed-out rates for different DM densities of silages, recommending the minimum feed-out rates to keep DM losses at feed-out below 3\% (Figure 13). They selected this level of loss at feed-out as an achievable goal using a wide combination of densities and feed-out rates. As previously stated, porosity (or bulk density) plays an important role in determining air penetration depth from the silo face together with covering type and how it is secured to the crop. Borreani and Tabacco (2010) proposed a method to quantify aerobic deterioration of corn silages using the temperature of silage mass at $200 \mathrm{~mm}$ behind the feed-out face of the silo combined with the extent of the visible mold on the silo face. This method is useful to detect early stages of the aerobic deterioration process and to improve silage management and was used by Borreani and Tabacco (2012a) to propose a minimum feed-out rate for whole-crop corn silage to dairy farmers of northern Italy in relation to season (Figure 14). Over winter, silages consumed with a feedout rate greater than $1.10 \mathrm{~m} /$ wk had a moldy surface lower than $2 \%$, irrespective of other silo management practices, whereas over the summer the feed-out rate should be higher than $1.75 \mathrm{~m} /$ wk. Analyzing the suggested minimum feed-out rates in different dairy areas of the world (Table 6), there was a strong relationship with mean temperature of the season and the minimum suggested feed-out rates (Figure 15). Köhler et al. (2013) analyzing 48 farm-scale silos found feed-out rate had a negative correlation with DM losses both for corn $(-0.555)$ and for grass $(-0.570)$ silages (Table 3$)$. Furthermore, they found a negative correlation of DM losses and DM density in corn silages $(-0.625)$, whereas no correlation was found for grass silages. Clark et al. (2008) in Wisconsin suggested the removal rates from a bunker/pile silo should never be lower than $0.7 \mathrm{~m} / \mathrm{wk}$ in the summer and $0.5 \mathrm{~m} / \mathrm{wk}$ in the winter. This was confirmed by observation in northern Italy by Borreani

Table 5. The effects of unloading rate, depth of air penetration from the silo face, and aerobic stability of silage upon exposure to air on silage temperature and $\mathrm{NE}_{\mathrm{L}}$ (from Honig et al., 1999)

\begin{tabular}{|c|c|c|c|c|c|c|c|}
\hline \multirow{3}{*}{$\begin{array}{l}\text { Feed-out rate } \\
(\mathrm{m} / \mathrm{wk})\end{array}$} & \multirow{3}{*}{$\begin{array}{l}\text { Air penetration from } \\
\text { the silo face }(\mathrm{m})\end{array}$} & \multicolumn{6}{|c|}{ Stability of silage under air exposure (d) } \\
\hline & & \multicolumn{3}{|c|}{$\begin{array}{c}\text { Temperature rise above } \\
\text { ambient at unloading }\left({ }^{\circ} \mathrm{C}\right)\end{array}$} & \multicolumn{3}{|c|}{$\mathrm{NE}_{\mathrm{L}}$ losses $(\%)$} \\
\hline & & 1 & 3 & 7 & 1 & 3 & 7 \\
\hline \multirow[t]{2}{*}{1.0} & 1 & 23 & 16 & 0 & 16 & 8 & 0 \\
\hline & 2 & 27 & 27 & 27 & 38 & 34 & 21 \\
\hline \multirow[t]{2}{*}{2.0} & 1 & 11 & 4 & 0 & 4 & 1 & 0 \\
\hline & 2 & 23 & 16 & 0 & 16 & 8 & 0 \\
\hline \multirow[t]{2}{*}{3.0} & 1 & 4 & 0 & 0 & 1 & 0 & 0 \\
\hline & 2 & 14 & 5 & 0 & 7 & 2 & 0 \\
\hline
\end{tabular}




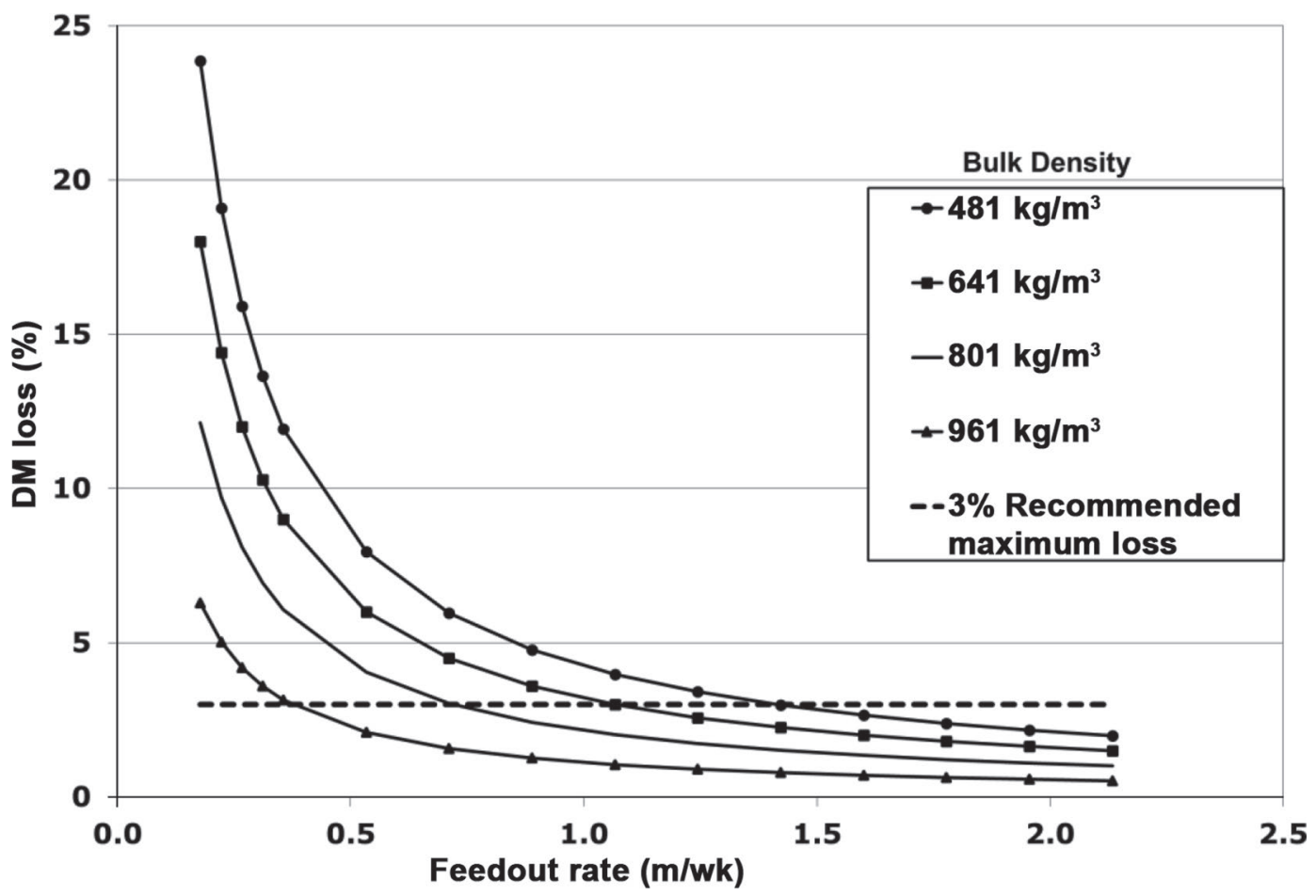

Figure 13. Dry matter loss at the feed-out face of a silo as influenced by bulk density and feed-out rate (adapted from Holmes and Muck, 2007).

and Tabacco (2012a), who found severely deteriorated silages when the feed-out rate was below 0.5 and $0.8 \mathrm{~m} /$ wk, during winter and summer, respectively.

\section{TOOLS TO DETERMINE SILAGE STATUS DURING FEED-OUT}

The importance of a uniform high quality silage over the whole profile of the silo has recently been stated by several researchers (Borreani and Tabacco, 2010; Muck,
2013; Wilkinson and Davies, 2013). As highlighted above, the improper incorporation of deteriorated feed from the top layers of the silo in the feed mixer could (1) increase contamination of the ration with undesirable microorganisms, such as filamentous fungi, aerobic and anaerobic spores (Borreani et al., 2013; Dunière et al., 2013), and harmful mycotoxins (Cavallarin et al., 2011; Wambacq et al., 2016); and (2) could potentiality reduce DMI (Gerlach et al., 2013) and dairy cow performance (Hoffman and Ocker, 1997). During feed-out,

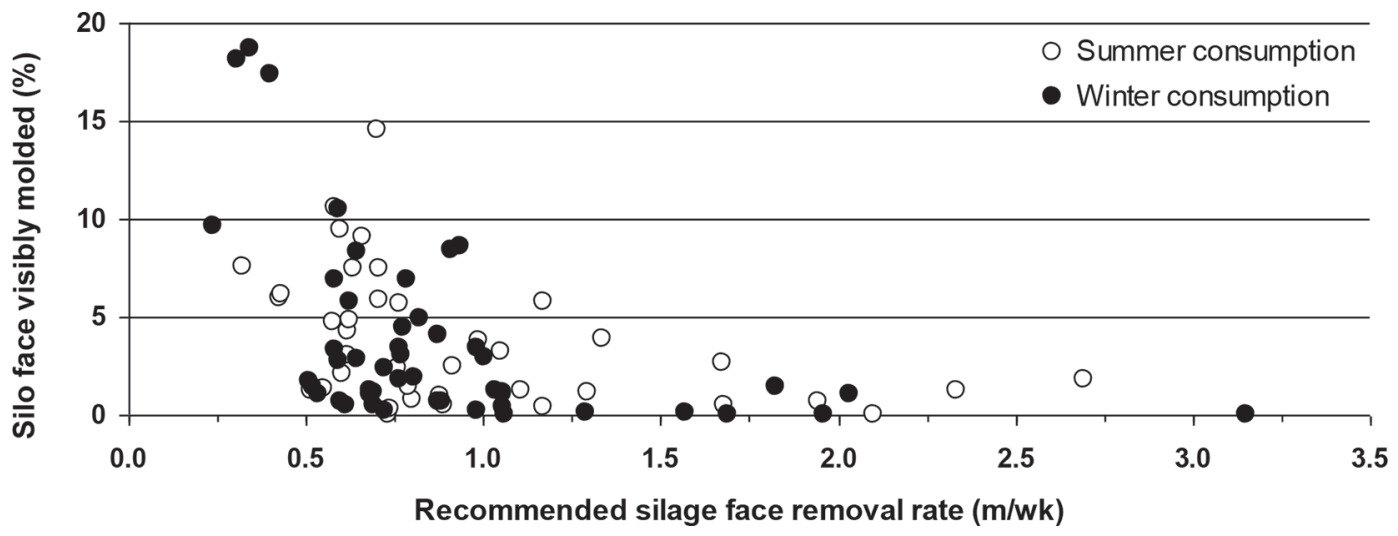

Figure 14. Percentage of the molded surface of the silo face of farm maize silages in relation to the weekly feed-out rate in northern Italy (from Borreani and Tabacco, 2012a). 
Table 6. Minimum seasonal recommended weekly unloading rates from bunker silos during feed-out related to latitude in different countries or US states

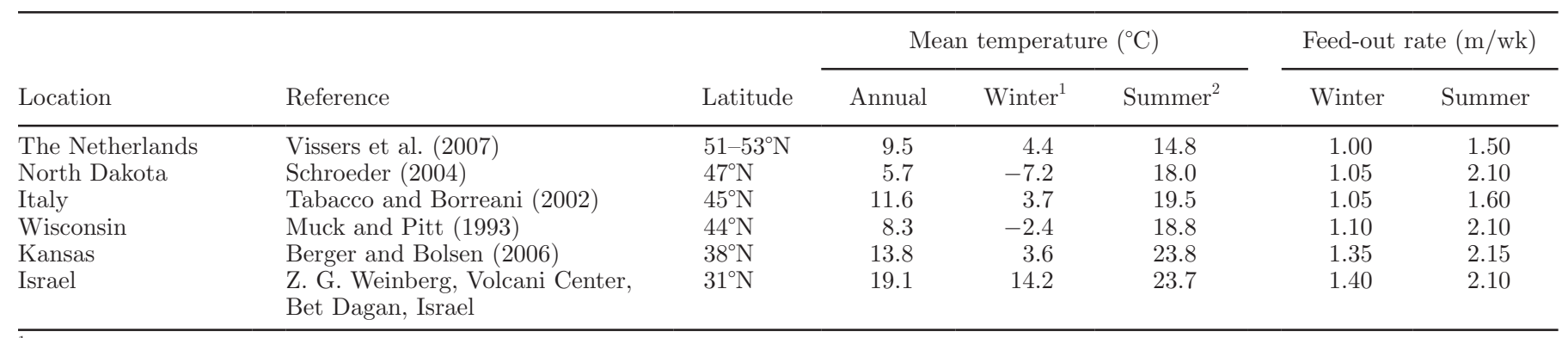

${ }^{1}$ Average monthly temperature for November to March.

${ }^{2}$ Average monthly temperature for May to September.

different stages of aerobic deterioration can be present at the same time at the silo face. Moldy silage can be easily appraised visually; unfortunately, there may be other parts of the silage face that are rapidly spoiling but appear no different than stable silage. Ideally one would like to detect all spoiling silage and avoid its inclusion in the feed ration. The accurate evaluation of the microbiological and chemical quality of the whole working face would require many samples, expensive labor and equipment, qualified personnel, and time-consuming laboratory analyses and could not be performed routinely on the farm during the feed-out phase. Hence, a simple method of enabling technicians and farmers to accurately and quickly assess and quantify silage quality and the extent of aerobic deterioration at the silo face is necessary.

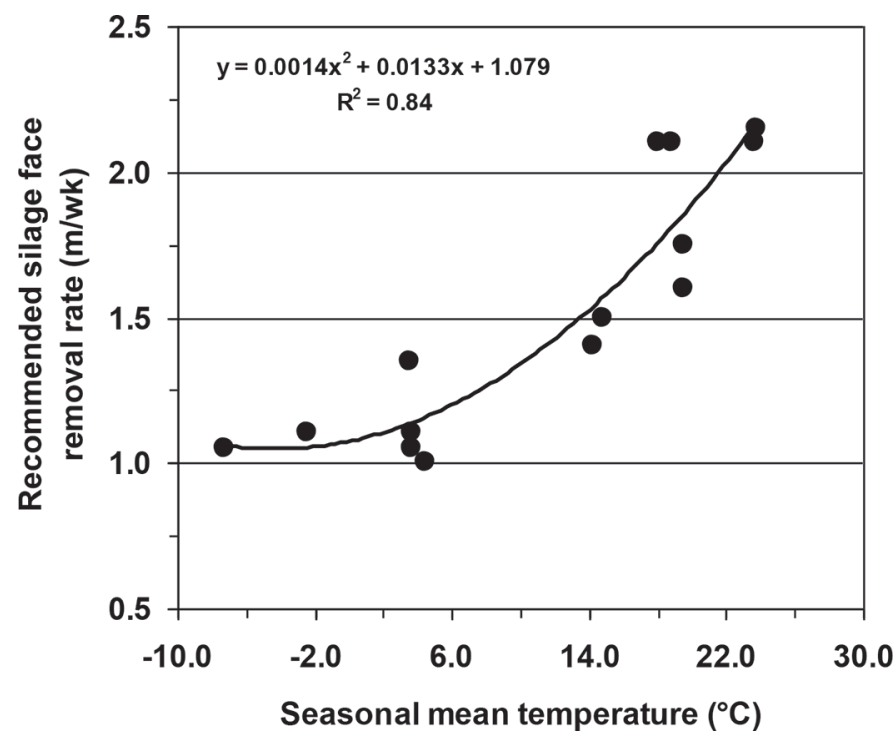

Figure 15. Recommended silage face removal rate to avoid aerobic deterioration from bunker silos in relation with mean seasonal temperature (from Borreani and Tabacco, 2012a).
During over exposure to air, lactate-utilizing yeasts proliferate and oxidize lactic acid, acetic acid, and water-soluble carbohydrates producing carbon dioxide and water, with the evolution of heat (McDonald et al., 1991). With the complete oxidation of glucose the temperature rise in the silage mass, assuming a specific heat capacity of $1.89 \mathrm{~kJ} / \mathrm{kg}$ per ${ }^{\circ} \mathrm{C}$ for the silage DM and no loss of heat to the atmosphere is given by the expression (McDonald and Whittenbury, 1973):

$$
\begin{gathered}
\text { temperature rise }\left({ }^{\circ} \mathrm{C}\right)=(\mathrm{DM} \times \text { glucose }) / \\
(267.5-0.147 \times \mathrm{DM})
\end{gathered}
$$

where DM $=$ DM content $(\mathrm{g} / \mathrm{kg})$; and glucose $=$ glucose oxidized $(\mathrm{g} / \mathrm{kg}$ of $\mathrm{DM})$. For example, the temperature rise through the complete oxidation of sugars in an insulated silage of DM content $320 \mathrm{~g} / \mathrm{kg}$ and sugar content (as glucose) of $50 \mathrm{~g} / \mathrm{kg}$ of DM would be $73^{\circ} \mathrm{C}$. In most practical situations, a part of the heat produced through oxidation is dissipated into the atmosphere, although temperature rises as high as $50^{\circ} \mathrm{C}$ have been recorded in aerobically deteriorated silages (Henderson et al., 1982). Because the oxidation process is accompanied by the evolution of heat, an increase in temperature is a convenient indicator of the extent and intensity of aerobic deterioration in both experimental and practical conditions (Honig and Woolford, 1980; Williams et al., 1994) and could have application in alerting farmers to the onset of aerobic deterioration (Tabacco and Borreani, 2002).

Several systems to measure temperature of the working face of a silo can describe the areas involved in aerobic microbial activity that are otherwise invisible. One method consists in burying temperature loggers inside the silo at the time of silo filling and retrieving them at feed-out (Kung, 2011). This option is very expensive and allows measurements only at some points of the silage mass in experimental protocols. Green et al. (2009) proposed burying wireless sensor nodes to 
precisely monitor and measure the temperature inside a silage stack. These sensors reliably transmit the data to a network model to predict the normal temperature variations of the silage using the air and soil temperature as inputs, and could detect the abnormal temperature variations inside the silage caused by silage deterioration.

An option to measure temperature at the silo face is to use a probe or "spike" thermometer. A first attempt to establish which area of the silo was subjected to aerobic deterioration at the farm level by means of a probe thermometer was made by Ruppel et al. (1995). These authors measured temperatures inside stored silage during feed-out at depths of $200 \mathrm{~mm}$ at various locations across the working face and then used the difference between silage temperature and ambient temperature as an index of heating associated with aerobic deterioration. The main problem of this method is the ambient temperature is not always a suitable reference, especially in temperate environments where it is subject to seasonal and daily fluctuations (Borreani and Tabacco, 2010). Borreani and Tabacco (2010) proposed to construct virtual thermograms of the feed-out face after measuring the temperature of the face with probe thermometers. They cored the faces of 54 maize silage bunker silos in northern Italy measuring fermentation products, yeasts, molds, clostridial spores and also taking temperatures at $200 \mathrm{~mm}$ behind the feed-out face. They compared these temperatures with the temperature in the middle of the face at $400 \mathrm{~mm}$ depth, where temperature is relatively constant, similar to temperatures deeper in the bunker. The $200 \mathrm{~mm}$ temperature at a specific location minus the temperature at $400 \mathrm{~mm}$ in the middle of the bunker was positively correlated with $\mathrm{pH}$, yeast, and mold counts. This suggests temperature measurements at the farm could be used to rapidly estimate yeast counts and assess the aerobic stability of silage. Muck (2013) expressed an interest in knowing if differences in silage temperature are a good predictor of fungal counts in more severe climates.

Another method proposed to measure temperature at the working face is by using heat-sensing digital cameras (Cassinis et al., 1993). Infrared thermography is a noninvasive technique capable of detecting thermal radiation from the surface of any object, and it has been widely used in animal diagnostics (e.g., McManus et al., 2016), to assess the safety and quality of agricultural products (Gowen et al., 2010), and to detect grain spoilage (Manickavasagan et al., 2006). Heatsensing digital cameras can capture in a single picture all temperatures of the working face, and may reduce costs associated with personnel and chemical reagents used for conventional assessment of silage aerobic stability (Addah et al., 2012). The first attempt to use this technique to assess the heat production at the silage face was made in 1993 by Cassinis et al., working on bunkers of corn, Italian ryegrass, and alfalfa silages. These authors concluded the temperatures measured on the silo face could be correlated with the heat status of the silage, even if the values were always lower than those measured in the silage mass to a depth of 120 $\mathrm{mm}$. The same results were reported by Collombier et al. (2001), who used infrared thermography for visualizing deterioration of corn silage and for testing the efficacy of an $L$. buchneri inoculant on silage aerobic stability. These authors found the surface temperatures were lower than those measured by probe thermometer to a depth of $150 \mathrm{~mm}$ in the silage mass, especially in the peripheral areas, where the heat production rate generated by aerobic deterioration is higher than in the silo core. Furthermore, temperature measurement by infrared thermography is highly influenced by weather (sunny, cloudy, rainy, and so on); the time of day; the exposure of the silo face to direct sunlight, wind, and so on; and the homogeneity of the feed-out face (Cassinis et al., 1993; Collombier et al., 2001). To overcome these issues, Clemente et al. (2015) proposed reliable data could be obtained by removing about $0.1 \mathrm{~m}$ from the silo face before shooting the image.

\section{RECOMMENDATIONS AND FUTURE PERSPECTIVES}

This paper has emphasized the importance of a uniform high-quality silage over the whole profile of the silo. Paying particular attention to reduce the direct and indirect DM and quality losses while improving the microbial and safety quality of silage, especially in the periphery of the silo, is imperative to maximize the efficiency of the ensiling process in a modern and sustainable dairy farm.

The technical and research innovations acquired in the last $15 \mathrm{yr}$ in the field of ensiling provide the opportunity to successfully plan farm silage making, maximizing nutritional quality and minimizing DM losses. Application of management practices, in view of a perfect silo setup and targeting conservation for longer than $1 \mathrm{yr}$, begins in the field and continues throughout the ensiling process until silage is in the feed-bunk. Harvesting the forage crop at the proper stage of maturity and moisture content (both direct cut and field-cured crops) allow the maximum digestible yield, high palatability, and maximum potential animal intake. Forage requiring wilting to a correct DM concentration before ensiling should be cut with a mower conditioner and wilted in a wide swath to reduce field wilting time and retain the maximum content of soluble carbohydrates and digestible nutrients. At harvest, inoculants can help to minimize losses in 
the silo. The type of inoculant depends on the most common microbial problem affecting losses and quality. Where inhibiting clostridial activity is the primary issue, traditional homofermentative strains are the most beneficial, lowering $\mathrm{pH}$ more rapidly and further than in an untreated crop. Where aerobic deterioration and spoilage is the primary concern, for corn silage the use of a combination inoculant containing both traditional homofermentative strains and L. buchneri provide a rapid drop in $\mathrm{pH}$ and the production of acetic acid in the later stages of storage to reduce the yeast count and inhibit their growth when oxygen is present. The forage should be packed, to a proper bulk density of at least $705 \mathrm{~kg} / \mathrm{m}^{3}$ to limit porosity, in a horizontal silo in the least time possible. An effective seal should be provided as quickly as possible after the silo is full, using a plastic with low oxygen permeability, well secured to the crop and to the silo structure. The practice of lining the walls of bunker silos with plastic, lapping the plastic over the forage and applying a top layer of plastic is highly recommended. The silo face should be sized to allow at least the minimum required removal rate in relation to the climatic conditions and the type of silage crop. All these practices contribute to the goal of reducing losses to a minimum, and maintaining highest quality, during the conservation period and the feed-out phase.

Future investigations should consider increasing ensiling efficiency in terms of more effective and environmentally sustainable ways of sealing (i.e., biobased biodegradable plastic), the use of cost-effective inoculants/additives that increase aerobic stability in the early stage of conservation (i.e., less than $30 \mathrm{~d}$ ) to increase flexibility in the use of silage, equipment for packing forage more efficiently, methods for removing top spoiled silage more safely and efficiently, improved methods for detecting and alerting producers to holes in plastic, aerobic spoilage events, and other issues affecting losses and silage quality.

\section{REFERENCES}

Addah, W., J. Baah, E. K. Okine, and T. A. McAllister. 2012. Use of thermal imaging and the in situ technique to assess the impact of an inoculant with feruloyl esterase activity on the aerobic stability and digestibility of barley silage. Can. J. Anim. Sci. 92:381-394. https://doi.org/10.4141/CJAS2012-016.

Adesogan, A. T. 2009. Challenges of tropical silage production. Pages 139-154 in Proc. 15th Int. Silage Conf., Madison, WI. G. A. Broderick, A. C. Adesogan, L. W. Bocher, K. K. Bolsen, F. E. Contreras-Govea, J. H. Harrison, and R. E. Muck, ed.

Adesogan, A. T., and Y. C. Newman. 2014. Silage harvesting, storing and feeding. IFAS Extension, University of Florida, Gainesville. Accessed May 19, 2017. Http://edis.ifas.ufl.edu/pdffiles/AG/ AG18000.pdf.

Adesogan, A. T., and M. B. Salawu. 2004. Effect of applying formic acid, heterolactic bacteria or homolactic and heterolactic bacteria on the fermentation of bi-crops of peas and wheat. J. Sci. Food Agric. 84:983-992. https://doi.org/10.1002/jsfa.1745.

Allred, K. R., W. K. Kennedy, L. S. Wittwer, G. W. Trimberger, J. T. Reid, and J. K. Loosli. 1955. Effects of preservatives upon red clover and grass forage ensiled without wilting. Part I. Storage losses. Cornell Univ. Agric. Exp. Sta. Bull. 912.

Anonymous. 1953. Packaged silage: Will plastics replace silos? New Jersey Agric. 35:4-5.

Arriola, K. G., S. C. Kim, and A. T. Adesogan. 2011. Effect of applying inoculants with heterolactic or homolactic and heterolactic bacteria on the fermentation and quality of corn silage. J. Dairy Sci. 94:1511-1516. https://doi.org/10.3168/jds.2010-3807.

Ashbell, G., and N. Lisker. 1988. Aerobic deterioration in maize silage stored in a bunker silos under farm conditions in a subtropical climate. J. Sci. Food Agric. 45:307-315.

Ashbell, G., and Z. G. Weinberg. 1992. Top silage losses in horizontal silos. Can. J. Eng. 34:171-175.

Ashbell, G., Z. G. Weinberg, A. Azrieli, Y. Hen, and B. Horev. 1991. A simple system to study the aerobic deterioration of silages. Can. Agric. Eng. 33:171-175.

Ashbell, G., Z. G. Weinberg, Y. Hen, and I. Filya. 2002. The effects of temperature on the aerobic stability of wheat and corn silages. J. Ind. Microbiol. Biotechnol. 28:261-263. https://doi.org/10.1038/ $\mathrm{sj} / \mathrm{jim} / 7000237$.

Auerbach, H., and E. Nadeau. 2013. Effects of chemical additives on whole crop maize silage traits. in Proc. 22 Int. Grassl. Congr., Sydney, New South Wales, Australia, Michalk, D. L., G. D. Millar, W. B. Badgery, and K. M. Broadfoot, ed. New South Wales Department of Primary Industry, Orange, New South Wales Australia.

Berger, L. L., and K. K. Bolsen. 2006. Sealing strategies for bunker silos and drive-over piles. Pages 1-18 in Proc. Silage for Dairy Farms: Growing, Harvesting, Storing, and Feeding. NRAES 181. Ithaca, NY.

Bernardes, T. F., I. L. De Oliviera, M. A. S. Lara, D. R. Casagrande, C. L. S. Avila, and O. G. Pereira. 2014. Effects of potassium sorbate and sodium benzoate at two application rates on fermentation and aerobic stability of maize silage. Grass Forage Sci. 70:491-498. https://doi.org/10.1111/gfs.12133.

Bernardes, T. F., L. G. Nussio, and R. C. Amaral. 2012. Top spoilage losses in maize silage sealed with plastic films with different permeabilities to oxygen. Grass Forage Sci. 67:34-42. https://doi.org/ 10.1111/j.1365-2494.2011.00823.x.

Bichert, W. G., B. Holmes, K. Janni, D. Kammel, R. Stowell, and J. Zulovich. 2000 Dairy Freestall Housing and Equipment. 7th ed, MWPS, MidWest Plan Service, Iowa State University, Ames.

Bolsen, K. K. 1997. Issues of top spoilage losses in horizontal silos. Pages 137-149 in Proc. North American Silage Conf. NRAES-99. Northeast Regional Agricultural Engineering Services, Ithaca, NY.

Bolsen, K. K. 2006. Silage management: common problems and their solution. Pages 83-93 in Tri-State Dairy Nutrition Conference, Wayne, IN.

Bolsen, K. K., R. Bolsen, S. Wigley, S. Ryan, and R. Kuber. 2012. Economics of sealing maize silage in bunker silos and drive-over piles: An Excel spreadsheet. Pages $286-287$ in Proc. 16th Int. Silage Conf. Kuoppala, K., M. Rinne, A. Vanhatalo (eds), MTT Agrifood Research Finland, Hämeenlinna, Finland.

Bolsen, K. K., J. T. Dickerson, B. E. Brent, R. N. Sonon, B. S. Dalke, C. Lin, and J. E. Boyer Jr. 1993. Rate and extent of top spoilage losses in horizontal silos. J. Dairy Sci. 76:2940-2962.

Bolsen, K. K., L. A. Whitlock, T. Wistuba, and R. V. Pope. 2001. Effect of level of surface spoilage on the nutritive value of wholecrop maize silage diets. Pages 174-175 in Proc. 10th International Symposium of Forage Conservation. V. Jambor, P. Dolezal, L. Zeman, R. Loucka, S. Rudolfova, and P. Prochazka, ed. Brno, Czech Republic.

Borreani, G., T. F. Bernades, and E. Tabacco. 2008. Aerobic deterioration influences the fermentative, microbiological and nutritional quality of maize and sorghum silages on farm in high quality milk and cheese production chains. Revista Brasileira de Zootecnia 37(Sup. Esp.):68-77. 
Borreani, G., P. Dolci, E. Tabacco, and L. Cocolin. 2013. Aerobic deterioration stimulates outgrowth of spore-forming Paenibacillus in corn silage stored under oxygen-barrier or polyethylene films. J. Dairy Sci. 96:5206-5216. https://doi.org/10.3168/jds.2013-6649.

Borreani, G., S. Piano, and E. Tabacco. 2014. Aerobic stability of maize silage stored under plastic films with different oxygen permeability. J. Sci. Food Agric. 94:2684-2690. https://doi.org/10 $.1002 /$ jsfa.6609.

Borreani, G., and E. Tabacco. 2008. Low permeability to oxygen of a new barrier film prevents butyric acid bacteria spore formation in farm maize silage. J. Dairy Sci. 91:4272-4281. https://doi.org/10 $.3168 /$ jds.2008-1151.

Borreani, G., and E. Tabacco. 2010. The relationship of silage temperature with the microbiological status of the face of corn silage bunkers. J. Dairy Sci. 93:2620-2629. https://doi.org/10.3168/jds .2009-2919.

Borreani, G., and E. Tabacco. 2012a. Effect of silo management factors on aerobic stability and extent of spoilage in farm maize silages. Pages 71-72 in Proc. 16th Int. Silage Conf. K. Kuoppala, M. Rinne, and A. Vanhatalo, ed. MTT Agrifood Research Finland, Hämeenlinna, Finland.

Borreani, G., and E. Tabacco. 2012b. Special EVOH-based films with lowered oxygen permeability reduce dry matter losses and increase aerobic stability of farm maize silages. Pages 302-303 in Proc. 16th Int. Silage Conf. K. Kuoppala, M. Rinne, and A. Vanhatalo, ed. MTT Agrifood Research Finland, Hämeenlinna, Finland.

Borreani, G., and E. Tabacco. 2014. Improving corn silage quality in the top layer of farm bunker silos through the use of a next-generation barrier film with high impermeability to oxygen. J. Dairy Sci. 97:2415-2426. https://doi.org/10.3168/jds.2013-7632.

Borreani, G., and E. Tabacco. 2017. Charter 9: Plastics in animal production. Pages 145-185 in A Guide to the Manufacture, Performance, and Potential of Plastics in Agriculture. M. Orzolek, ed. Elsevier Ltd., Amsterdam, the Netherlands. https://doi.org/10 .1016/B978-0-08-102170-5.00009-9.

Borreani, G., E. Tabacco, and L. Cavallarin. 2007. A new oxygen barrier film reduces aerobic deterioration in farm-scale corn silage. J. Dairy Sci. 90:4701-4706. https://doi.org/10.3168/jds.2007-0310.

Borreani, G., E. Tabacco, and A. Ciotti. 1999. Effects of mechanical conditioning on wilting of alfalfa and Italian ryegrass for ensiling. Agron. J. 91:457-463.

Brito, A. F., G. F. Tremblay, A. Bertrand, Y. Castonguay, G. Bélanger, R. Michaud, H. Lapierre, C. Benchaar, H. V. Petit, D. R. Ouellet, and R. Berthiaume. 2008. Alfalfa cut at sundown and harvested as baleage improves milk yield of late-lactation dairy cows. J. Dairy Sci. 91:3968-3982. https://doi.org/10.3168/jds.2008 -1282 .

Brüning, D., K. Gerlach, K. Weiß, and K. H. Südekum. 2018. Effect of compaction, delayed sealing and aerobic exposure on maize silage quality and on formation of volatile organic compounds. Grass Forage Sci. 73:53-66. https://doi.org/10.1111/gfs.12288.

Cassinis, C., F. Pagnoni, and R. Tomasoni. 1993. Analisi di insilati per foraggiamento mediante termografia (Forage silage analysis by infrared thermography). Inf. Agric. 49:67-73.

Cavallarin, L., E. Tabacco, S. Antoniazzi, and G. Borreani. 2011. Aflatoxin accumulation in whole crop maize silage as a result of aerobic exposure. J. Sci. Food Agric. 91:2419-2425. https://doi .org/10.1002/jsfa.4481.

Clark, J., B. Holmes, and R. E. Muck. 2008. Feedout losses from forage storage systems. Focus on Forage 4:1-3.

Clemente, G., J. L. Monge, F. M. Clemente, and K. D. Cervigni. 2015. Use of thermographic images for evaluation of superficial and subsurface temperature in the exposed area of corn silos. Pages 308309 in Proc. 17th Int. Silage Conf., Piracicaba, São Paulo, Brazil.

Collombier, J., E. Daburon, Y. Gallard, and B. Bailhache. 2001. Utilization of infrared thermography for visualizing aerobic deteriorations of maize silage and efficacy of a silage inoculant. In Proc. 8th Rencontres Autour des Recherches sur les Ruminants, Paris, France.

Condon, S. 1987. Responses of lactic acid bacteria to oxygen. FEMS Microbiol. Lett. 46:269-280.
Craig, P. H., K. E. Griswold, and S. K. Dinh. 2009. Six years of corn silage density evaluations in south central Pennsylvania. Pages 223-224 in Proc. 15th Int. Silage Conf. G. A. Broderick, A. C. Adesogan, L. W. Bocher, K. K. Bolsen, F. E. Contreras-Govea, J. H. Harrison, and R. E. Muck, ed. Madison, Wisconsin.

Craig, P. H., and G. Roth. 2005. Penn State University bunker silo density study summary report 2004-2005. Pennsylvania State University.

De Angelis, D. 2012. High barrier resin for all silage applications Pages 4.21-4.45 in Agricultural Film 2012: Int. Conf. Agric. Horticultural Film Industry. Applied Market Information Ltd., Madrid, Spain.

Dickerson, J. T., G. Ashbell, L. Pfaff, K. K. Bolsen, B. E. Brent, J. E. Bradford, and R. L. Smith. 1991. Top spoilage losses in horizontal silos in western Kansas. Pages 71-74 in Cattlemen's Day, Progress Report. Kansas State Univ., Manhattan.

Dolci, P., E. Tabacco, L. Cocolin, and G. Borreani. 2011. Microbial dynamics during aerobic exposure of corn silage stored under oxygen barrier or polyethylene films. Appl. Environ. Microbiol. 77:7499 7507. https://doi.org/10.1128/AEM.05050-11.

Driehuis, F. 2013. Silage and the safety and quality of dairy foods: A review. Agric. Food Sci. 22:16-34.

Driehuis, F., S. J. W. H. Oude Elferink, and S. F. Spoelstra. 1999. Anaerobic lactic acid degradation during ensilage of whole crop maize inoculated with Lactobacillus buchneri inhibits yeast growth and improves aerobic stability. J. Appl. Microbiol. 87:583-594.

Driehuis, F., S. J. W. H. Oude Elferink, and P. G. Van Wikselaar. 2001. Fermentation characteristics and aerobic stability of grass silage inoculated with Lactobacillus buchneri, with or without homofermentative lactic acid bacteria. Grass Forage Sci. 56:330-343. https://doi.org/10.1046/j.1365-2494.2001.00282.x.

Dunière, L., J. Sindou, F. Chaucheyras-Durand, I. Chevallier, and D. Thévenot-Sergentet. 2013. Silage processing and strategies to prevent persistence of undesirable microorganisms. Anim. Feed Sci. Technol. 182:1-15. https://doi.org/10.1016/j.anifeedsci.2013 .04 .006 .

Gerlach, K., Y. Liao, and K. H. Sudekum. 2014a. Aerobic exposure of lucerne silages and its impact on preference and dry matter intake by goats. Small Rumin. Res. 121:308-313. https://doi.org/ 10.1016/j.smallrumres.2014.07.022

Gerlach, K., K. Weiss, F. Ross, W. Buscher, and K. H. Sudekum. 2013. Changes in maize silage fermentation products during aerobic deterioration and its impact on feed intake by goats. Agric. Food Sci. 22:168-181.

Gerlach, K., K. Weiss, F. Ross, W. Buscher, and K. H. Sudekum. 2014b. Aerobic exposure of grass silages and its impact on dry matter intake and preference by goats. Small Rumin. Res. 117:131141. https://doi.org/10.1016/j.smallrumres.2013.12.033.

Gowen, A. A., B. K. Tiwari, P. J. Cullen, K. McDonnell, and C. P. O'Donnell. 2010. Applications of thermal imaging in food quality and safety assessment. Trends Food Sci. Technol. 21:190-200. https://doi.org/10.1016/j.tifs.2009.12.002.

Green, O., T. Bartzanas, M. M. Løkke, D. D. Bochtis, C. G. Sørensen, O. J. Jørgensen, and V. G. Tortajada. 2012. Spatial and temporal variation of temperature and oxygen concentration inside silage stacks. Biosyst. Eng. 111:155-165. https://doi.org/10.1016/ j.biosystemseng.2011.11.008.

Green, O., E. S. Nadimi, V. Blanes-Vidal, R. N. Jørgensen, I. M. L. D. Storm, and C. G. Sørensen. 2009. Monitoring and modeling temperature variations inside silage stacks using novel wireless sensor networks. Comput. Electron. Agric. 69:149-157. https://doi.org/ 10.1016/j.compag.2009.07.021.

Griswold, K. E., P. H. Craig, and S. K. Dinh. 2009. Relating dry matter density to dry matter loss in corn silage bunker silos in Southeastern Pennsylvania. Pages 95-96 in Proc. 15th Int. Silage Conf., Broderick G. A., A. C. Adesogan, L. W. Bocher, K. K. Bolsen, F. E. Contreras-Govea, J. H. Harrison, and R. E. Muck, ed. Madison, Wisconsin.

Griswold, K. E., P. H. Craig, J. S. Graybill, and S. K. Dinh. 2010. Relating dry matter density to dry matter loss within corn silage bunker silos. Accessed Oct. 27, 2017. https://cdn.sare.org/ 
wp-content/uploads/20171204123853/195griswold-dry-matter-loss -poster-metric-version.pdf.

Hafner, S. D., R. B. Franco, L. Kung Jr., C. A. Rotz, and F. Mitloehner. 2014. Potassium sorbate reduces production of ethanol and 2 esters in corn silage. J. Dairy Sci. 97:7870-7878. https://doi .org/10.3168/jds.2014-8537.

Henderson, A. R., P. McDonald, and D. H. Anderson. 1982. The effect of silage additives containing formaldehyde on the fermentation of ryegrass ensiled at different dry matter levels and on the nutritive value of direct-cut silage. Anim. Feed Sci. Technol. 7:303-314.

Hoffman, P. C., and D. K. Combs. 2009. Molds and mycotoxins in corn silage and high moisture corn. Part I. Managing aerobic stability. Department of Dairy Science, University of Wisconsin-Madison. http://qualitysilage.com/wp-content/themes/.../Aerobic Stability.pdf

Hoffman, P. C., and S. M. Ocker. 1997. Quantification of milk yield losses associated with feeding aerobically unstable high moisture corn. J. Dairy Sci. 80(E-Suppl. 1):234. (Abstr.)

Holmes, B. J. 2005. Average density of silage in storage. University of Wisconsin-Extension, Team Forage-Harvest and Storage website. http://fyi.uwex.edu/forage/files/2014/02/StoredDensity1-28 $-05 . x l s$.

Holmes, B. J. 2006. Density in silage storage. Silage for Dairy Farms: Growing, Harvesting, Storing and Feeding Conference Proceedings (NRAES-181), Natural Resource, Agriculture and Engineering Service, Ithaca, NY.

Holmes, B. J., and K. K. Bolsen. 2009. What's new in silage management? Pages 61-76 in Proc. 15th Int. Silage Conf. G. A. Broderick, A. C. Adesogan, L. W. Bocher, K. K. Bolsen, F. E. ContrerasGovea, J. H. Harrison, and R. E. Muck, ed. Madison, Wisconsin.

Holmes, B. J., and R. E. Muck. 2007. Packing bunkers and piles to maximize forage preservation. Proc. 6th Int. Dairy Housing Conf. ASABE and Harvest and Storage. Accessed Jan. 15, 2017. http:// www.uwex.edu/ces/crops/uwforage/storage.htm.

Holmes, B. J., and R. E. Muck. 2009. Changing the way silage density is measured for more consistent porosity. Forage Focus-Equipment. Accessed Oct. 27, 2017. http://www.midwestforage.org/pdf/409 .pdf.pdf.

Holmes, B. J., and R. E. Muck. 2011a. Bunker silo density calculator. Accessed Mar. 30, 2017. http://fyi.uwex.edu/forage/files/2014/ 02/BunkDensCalc-7-21-11wPOROSITY-Russian.xls.

Holmes, B. J., and R. E. Muck. 2011b. Silage pile density calculator. Accessed Mar. 30, 2017. http://fyi.uwex.edu/forage/files/2014/ 02/PileDensCalcwPOROSITY8-24-07Edit-4-29-11.xls.

Honig, H. 1990. Evaluation of aerobic stability. Grass Forage Rep. Special issue. Pages 76-82 in Proc. EUROBAC Conf. 1986, Swedish University of Agricultural Sciences, Uppsala, Sweden.

Honig, H. 1991. Reducing losses during storage and unloading of silage. Pages 116-128 in Forage Conservation Towards 2000, G. Pahlow and H. Honig, ed. Landbauforschung Volkenrode, Sonderheft 123, Braunschweig, Germany.

Honig, H., G. Pahlow, and J. Thaysen. 1999. Aerobic instability-Effects and possibilities for its prevention. Pages 288-289 in Proc. 12th Int. Silage Conf., Uppsala, Sweden.

Honig, H., and M. K. Woolford. 1980. Changes in silage on exposure to air. Pages 76-87 in Proc. Occasional Symp. EGF Forage Conservation in the 80's. Br. Grassl. Soc. Hurley, UK.

Huisden, C. M., A. T. Adesogan, S. C. Kim, and T. Ososanya. 2009 Effect of applying molasses or inoculants containing homofermentative or heterofermentative bacteria at two rates on the fermentation and aerobic stability of corn silage. J. Dairy Sci. 92:690-697. https://doi.org/10.3168/jds.2008-1546.

Johnson, L. M., J. H. Harrison, D. Davidson, W. C. Mahanna, K. Shinners, and D. Linder. 2002. Corn silage management: Effects of maturity, inoculation, and mechanical processing on pack density and aerobic stability. J. Dairy Sci. 85:434-444. https://doi.org/10 .3168/jds.S0022-0302(02)74092-7.

Jones, R. 2001. Reducing silage loss. Livestock Knowledge Transfer. ADAS/IGER/University of Bristol, UK. Accessed Nov. 10, 2017. http://adlib.everysite.co.uk/adlib/defra/content.aspx?id=94779.
Kang, T. W., A. T. Adesogan, S. C. Kim, and S. S. Lee. 2009. Effects of an esterase-producing inoculant on fermentation, aerobic stability, and neutral detergent fiber digestibility of corn silage. J. Dairy Sci. 92:732-738. https://doi.org/10.3168/jds.2007-0780.

Kim, S. C., and A. T. Adesogan. 2006. Influence of ensiling temperature, simulated rainfall, and delayed sealing on fermentation characteristics and aerobic stability of corn silage. J. Dairy Sci. 89:3122-3132. https://doi.org/10.3168/jds.S0022-0302(06)72586 $-3$.

Kleinschmit, D. H., and L. Kung Jr. 2006. A meta-analysis of the effects of Lactobacillus buchneri on the fermentation and aerobic stability of corn and grass and small-grain silages. J. Dairy Sci. 89:4005-4013. https://doi.org/10.3168/jds.S0022-0302(06)72444 -4 .

Kleinschmit, D. H., R. J. Schmidt, and L. Kung Jr. 2005. The effects of various antifungal additives on the fermentation and aerobic stability of corn silage. J. Dairy Sci. 88:2130-2139. https://doi .org/10.3168/jds.S0022-0302(05)72889-7.

Knicky, M., and R. Spörndly. 2011. The ensiling capability of a mixture of sodium benzoate, potassium sorbate, and sodium nitrite. J. Dairy Sci. 94:824-831. https://doi.org/10.3168/jds.2010-3364.

Köhler, B., M. Diepolder, J. Ostertag, S. Thurner, and H. Spiekers 2013. Dry matter losses of grass, lucerne and maize silages in bunker silos. Agric. Food Sci. 22:145-150.

Korosteleva, S. N., T. K. Smith, and H. J. Boermans. 2007. Effects of feedborne Fusarium mycotoxins on the performance, metabolism, and immunity of dairy cows. J. Dairy Sci. 90:3867-3873. https:// doi.org/10.3168/jds.2007-0162.

Kristensen, N. B., K. H. Sloth, O. Højberg, N. H. Spliid, C. Jensen, and R. Thøgersen. 2010. Effects of microbial inoculants on corn silage fermentation, microbial contents, aerobic stability, and milk production under field conditions. J. Dairy Sci. 93:3764-3774. https://doi.org/10.3168/jds.2010-3136.

Krooneman, J., F. Faber, A. C. Alderkamp, S. J. W. H. Oude Elferink, F. Driehuis, I. Cleenwerck, J. Swings, J. C. Gottschal, and M. Vancanneyt. 2002. Lactobacillus diolivorans sp. Nov., a 1,2-propanediol-degrading bacterium isolated from aerobically stable maize silage. Int. J. Syst. Evol. Microbiol. 52:639-646. https://doi.org/ 10.1099/00207713-52-2-639.

Kung, L., Jr. 2011. Silage temperatures: how hot is too hot? Available online at: https://cdn.canr.udel.edu/wp-content/uploads/2014/ 02/HowHotisTooHot-2011.pdf. Accessed on January 27, 2017.

Kung, L., Jr., J. R. Robinson, N. K. Ranjit, J. H. Chen, C. M. Golt, and J. D. Pesek. 2000. Microbial populations, fermentation endproducts, and aerobic stability of corn silage treated with ammonia or a propionic acid-based preservative. J. Dairy Sci. 83:1479-1486. https://doi.org/10.3168/jds.S0022-0302(00)75020-X.

Kung, L., Jr., A. C. Sheperd, A. M. Smagala, K. M. Endres, C. A. Bessett, N. K. Ranjit, and J. L. Glancey. 1998. The effect of preservatives based on propionic acid on the fermentation and aerobic stability of corn silage and a total mixed ration. J. Dairy Sci. 81:1322-1330. https://doi.org/10.3168/jds.S0022-0302(98)75695 -4 .

Kung, L., Jr., M. R. Stokes, and C. J. Lin. 2003. Silage additives, Pages 305-360 in Silage Science and Technology (Agronomy Series No. 42). Buxton D. R., R. E. Muck, and H. J. Harrison, ed. American Society of Agronomy, Madison, WI.

Kung, L., Jr., E. C. Stough, E. E. McDonell, R. J. Schmidt, M. W. Hofherr, L. J. Reich, and C. M. Klingerman. 2010. The effect of wide swathing on wilting times and nutritive value of alfalfa haylage. J. Dairy Sci. 93:1770-1773. https://doi.org/10.3168/jds .2009-2451.

Lättamäe, P., B. Osmane, I. H. Konosonoka, S. Wigley, and J. M. Wilkinson. 2012. Effect of a silo sealing system based on an oxygen barrier film on composition and losses from the upper layer of grass/clover crops ensiled in farm-scale silos. Agraarteadus (Tartu) 23:43-49.

Laue, A. 1990. Zur Problematik der dynamischen Verdichtung von Anwelkgras im Fahrsilo (Analysis of dynamic compression of wilted grass in horizontal silos). Diplomarbeit, Kiel, Germany. 
Lima, L. M., J. P. Dos Santos, D. R. Casagrande, C. L. S. Ávila, M. S. Lara, and T. F. Bernardes. 2017. Lining bunker walls with oxygen barrier film reduces nutrient losses in corn silages. J. Dairy Sci. 100:4565-4573. https://doi.org/10.3168/jds.2016-12129.

Lindgren, S., G. Pahlow, and E. Oldenburg. 2002. Influence of microbes and their metabolites on feed and food quality. Pages 503-511 in Proc. 19th Gen. Meet. EGF, La Rochelle, France. Br. Grassl. Soc., Reading, UK.

Lindgren, S., K. Pettersson, A. Kaspersson, A. Jonsson, and P. Lingvall. 1985. Microbial dynamics during aerobic deterioration of silages. J. Sci. Food Agric. 36:765-774.

Mahanna, B., and L. E. Chase. 2003. Practical applications and solutions to silage problems. Pages 855-895 in Silage Science and Technology. Vol. 42. D. R. Buxton, R. E. Muck, and J. H. Harrison, ed. ASA, CSSA, SSSA, Madison, WI.

Manickavasagan, A., D. S. Jayas, N. D. G. White, and F. Jian. 2006. Thermal imaging of a stored grain silo to detect a hot spot. Appl. Eng. Agric. 22:891-897.

McAllister, T. A., and A. N. Hristov. 2000. The fundamentals of making good quality silage. Adv. Dairy Technol. 12:381-399.

McDonald, P., A. R. Henderson, and S. J. E. Heron. 1991. The Biochemistry of Silage. 2nd ed. Chalcombe Publications, Bucks, UK.

McDonald, P., and R. Whittenbury. 1973. The ensilage process. Pages 33-60 in Chemistry and Biochemistry of Herbage. Vol. 3. G. W. Butler and R. W. Bailey, ed. Academic Press, NY.

McDonell, E. E., and L. Kung Jr. 2006. An update on covering bunker silos. University of Delaware, Newark. Accessed Jan. 23, 2017. https://cdn.canr.udel.edu/wp-content/uploads/2014/02/ CoveringBunkerSilos_000.pdf.

McEniry, J., P. O'Kiely, N. J. W. Clipson, P. D. Forristal, and E. M. Doyle. 2010. Assessing the impact of various ensilage factors on the fermentation of grass silage using conventional culture and bacterial community analysis techniques. J. Appl. Microbiol. 108:1584-1593. https://doi.org/10.1111/j.1365-2672.2009.04557.x.

McGuffey, R. K., and M. J. Owens. 1979. Effect of covering and dry matter at ensiling on preservation of alfalfa in bunker silos. J. Anim. Sci. 49:298-305.

McManus, C., C. B. Tanure, V. Peripolli, L. Seixas, V. Fischer, A. M. Gabbi, S. R. O. Menegassi, M. T. Stumpf, G. J. Kolling, E. Dias, and J. B. G. Costa Jr. 2016. Infrared thermography in animal production: An overview. Comput. Electron. Agric. 123:10-16. https://doi.org/10.1016/j.compag.2016.01.027.

Mills, J. A., and L. Kung Jr. 2002. The effect of delayed ensiling and application of a propionic acid-based additive on the fermentation of barley silage. J. Dairy Sci. 85:1969-1975.

Morin, C., G. F. Tremblay, G. Bélanger, A. Bertrand, Y. Castonguay, R. Drapeau, R. Michaud, R. Berthiaume, and G. Allard. 2012. Nonstructural carbohydrate concentration during field wilting of PM- and AM-cut alfalfa. Agron. J. 104:649-660. https://doi.org/ 10.2134/agronj2011.0365.

Muck, R. E. 2013. Recent advances in silage microbiology. Agric. Food Sci. $22: 3-15$

Muck, R. E., and J. T. Dickerson. 1988. Storage temperature effects on proteolysis in alfalfa silage. Trans. ASAE 31:1005-1009.

Muck, R. E., and B. J. Holmes. 2000. Factors affecting bunker silo densities. Appl. Eng. Agric. 16:613-619.

Muck, R. E., and B. J. Holmes. 2009. Influence of cover type on silage quality in bunker silos. Pages $277-278$ in Proc. 15th Int. Silage Conf., Broderick G. A., A. C. Adesogan, L. W. Bocher, K. K. Bolsen, F. E. Contreras-Govea, J. H. Harrison, and R. E. Muck, ed. Madison, Wisconsin.

Muck, R. E., B. J. Holmes, and P. Savoie. 2004a. Packing practice effects on density in bunker silos. ASABE Paper Number 041137, ASABE, St. Joseph, MI.

Muck, R. E., and L. Kung, Jr. 1997. Effects of silage additives on ensiling. Pages 187-199. In Silage: Field to Feedbunk. NRAES-99. Northeast Regional Agricultural Engineering Service, Hershey, PA.

Muck, R. E., L. E. Moser, and R. E. Pitt. 2003. Postharvest factors affecting ensiling. Pages 251-304 in Silage Science and Technology (Agronomy Series No. 42). D. R. Buxton, R. E. Muck, and H. J. Harrison, ed. American Society of Agronomy, Madison, WI.
Muck, R. E., and R. E. Pitt. 1993. Ensiling and its effect on crop quality. Page 57 in Proc. National Silage Prod. Conf., NRAES Cooperative Extension, Ithaca, NY.

Muck, R. E., M. C. Santos, L. Kung, Jr., E. M. G. Nadeau, T. A. McAllister, and F. E. Contreras-Govea. 2017. Recent advances and future uses of silage inoculants and additives. Submitted to J. Dairy Sci.

Muck, R. E., P. Savoie, and B. J. Holmes. 2004b. Laboratory assessment of bunker silo density. Part I: alfalfa and grass. Appl. Eng. Agric. 20:157-164.

Norell, R. J., S. Hines, M. Chahine, T. Fife, M. De Haro Marti, and S. Parkinson. 2013. Comparing three different methods for assessing corn silage density. J. Extension 51(5): 5RIB9. https://www.joe .org/joe/2013october/rb9.php.

Nutcher, K., R. Salacci, C. P. Kuber, R. Kuber, M. E. Uriarte, and K. K. Bolsen. 2015. Effects of sealing time post-filling and sealing material on fermentation, nutritional quality, and organic matter loss of whole-plant maize ensiled in a drive-over pile. Pages 320-321 in Proc. 17th Int. Silage Conf., Piracicaba, São Paulo, Brazil.

Ogunade, I. M., K. G. Arriola, Y. Jiang, J. P. Driver, C. R. Staples, and A. T. Adesogan. 2016. Effects of 3 sequestering agents on milk aflatoxin $\mathrm{M}_{1}$ concentration and the performance and immune status of dairy cows fed diets artificially contaminated with aflatoxin B $_{1}$. J. Dairy Sci. 99:6263-6273. https://doi.org/10.3168/jds.2016 -10905 .

Oliveira, A. S., Z. G. Weinberg, I. M. Ogunade, A. A. P. Cervantes, K. G. Arriola, Y. Jiang, D. Kim, X. Li, M. C. M. Gonçalves, D. Vyas, and A. T. Adesogan. 2017. Meta-analysis of effects of inoculation with homofermentative and facultative heterofermentative lactic acid bacteria on silage fermentation, aerobic stability, and the performance of dairy cows. J. Dairy Sci. 100:4587-4603. https://doi .org/10.3168/jds.2016-11815.

Oude Elferink, S. J. W. H., E. J. Krooneman, J. C. Gottschal, S. F. Spoelstra, F. Faber, and F. Driehuis. 2001. Anaerobic conversion of lactic acid to acetic acid and 1,2-propanediol by Lactobacillus buchneri. Appl. Environ. Microbiol. 67:125-132.

Pahlow, G., R. E. Muck, F. Driehuis, S. J. W. H. Oude Elferink, and S. F. Spoelstra. 2003. Microbiology of ensiling. Pages 31-93 in Silage Science and Technology (Agronomy Series No. 42). D. R. Buxton, R. E. Muck, and H. J. Harrison, ed. American Society of Agronomy, Madison, WI.

Parvin, S., and N. Nishino. 2009. Bacterial community associated with ensilage process of wilted guinea grass. J. Appl. Microbiol. 107:2029-2036. https://doi.org/10.1111/j.1365-2672.2009.04391.x.

Pauly, T., and R. Spörndly. 2011. Minimum temperature for successful silage making. Pages 28 in 2nd Int. Symp. Forage Quality and Conservation. M. Zopollatto, J. L. P. Daniel, L. G. Nussio, and A. D. S. Neto, ed. University of Sao Paolo, Piracicaba, Brasil.

Pitt, R. E. 1983. Mathematical prediction of density and temperature of ensiled forage. Trans. ASAE 26:1522-1532.

Pitt, R. E. 1986. Dry matter losses due to oxygen infiltration into silos. J. Agric. Eng. Res. 35:193-205.

Pitt, R. E., and R. E. Muck. 1993. A diffusion model of aerobic deterioration at the exposed face of bunker silos. J. Agric. Eng. Res. $55: 11-26$

Pitt, R. E., R. E. Muck, and R. Y. Leibsensperger. 1985. A quantitative model of the ensiling process in lactate silages. Grass Forage Sci. 40:279-303.

Rankin, M., and D. Undersander. 2000. Rain damage to forage during hay and silage making. Focus on Forage 2:1-3.

Rees, D. V. H. 1982. The aerobic deterioration of grass silages and its effects on water-soluble carbohydrates and the associated heat production. J. Sci. Food Agric. 33:499-508.

Richard, E., N. Heutte, V. Bouchart, and D. Garon. 2009. Evaluation of fungal contamination and mycotoxin production in maize silage. Anim. Feed Sci. Technol. 148:309-320. https://doi.org/10.1016/j .anifeedsci.2008.02.004

Richard, T. L., A. H. M. Veeken, V. de Wilde, and H. V. M. Hamelers. 2004. Air-filled porosity and permeability relationships during solid-state fermentation. Biotechnol. Prog. 20:1372-1381. 
Robinson, P. H., and N. Swanepoel. 2016. Impacts of a polyethylene silage pile underlay plastic with or without enhanced oxygen barrier (EOB) characteristics on preservation of whole crop maize silage, as well as a short investigation of peripheral deterioration on exposed silage faces. Anim. Feed Sci. Technol. 215:13-24. https:// doi.org/10.1016/j.anifeedsci.2016.02.001.

Robinson, P. H., N. Swanepoel, J. M. Heguy, and D. M. Meyer. 2016. Total 'shrink' losses and where they occur in commercially sized silage piles constructed from mature and immature cereal crops. Sci. Total Environ. 559:45-52. https://doi.org/10.1016/j.scitotenv 2016.03.103.

Rooke, J. A., and R. D. Hatfield. 2003. Biochemistry of ensiling. Pages 95-139 in Silage Science and Technology (Agronomy Series No. 42). D. R. Buxton, R. E. Muck, and H. J. Harrison, ed. American Society of Agronomy, Madison, WI.

Rotz, C. A. 2003. How to maintain forage quality during harvest and storage. Pages 227-239 in Proc. of 2003 Western Canadian Dairy Seminar, Advances in Dairy Technology, vol. 15.

Rotz, C. A. 2005. Postharvest changes in alfalfa quality. Pages 253262. in Proc. 35th California Alfalfa and Forage Symp., UC Cooperative Extension, Agronomy Research and Extension Center, Plant Sciences Department, University of California, Davis.

Ruppel, K. A. 1992. Effect of bunker silo management on hay crop nutrient management. MS Thesis. Department of Agricultural and Biological Engineering, Cornell University, Ithaca, NY.

Ruppel, K. A. 1997. Economics of silage management practices: What can I do to improve the bottom line of my ensiling business? Pages 125-136 in Silage: Field to Feedbunk, NRAES-99, Northeast Regional Agricultural Engineering Service, Ithaca, NY.

Ruppel, K. A., R. E. Pitt, L. E. Chase, and D. M. Galton. 1995. Bunker silo management and its relationship to forage preservation on dairy farms. J. Dairy Sci. 78:141-153.

Salvo, P. A. R., E. P. Schonell, J. L. P. Daniel, M. C. Santos, G. Morais, J. P. Winckler, J. Silva, and L. G. Nussio. 2015. Effects of Pichia norvegensis and air exposure on the nutritive value of corn silages for dairy cows. Pages 70-71 in Proc. 17th Int. Silage Conf., Piracicaba, São Paulo, Brazil.

Santos, M. C., A. L. Lock, G. D. Mechor, and L. Kung Jr. 2015. Effects of a spoilage yeast from silage on in vitro ruminal fermentation. J. Dairy Sci. 98:2603-2610. https://doi.org/10.3168/jds.2014 $-8683$.

Savoie, P. 1988. Optimization of plastic covers for stack silos. J. Agric. Eng. Res. 41:65-73.

Savoie, P., and J. C. Jofriet. 2003. Silage strorage. Pages 405-467 in Silage Science and Technology (Agronomy Series No. 42). D. R Buxton, R. E. Muck, and H. J. Harrison, ed. American Society of Agronomy, Madison, WI.

Savoie, P., R. E. Muck, and B. J. Holmes. 2004. Laboratory assessment of bunker silo density. Part II: whole plant corn. Appl. Eng. Agric. 20:165-171.

Schmidt, R. J., and L. Kung Jr. 2010. The effects of Lactobacillus buchneri with or without a homolactic bacterium on the fermentation and aerobic stability of corn silage made at different locations. J. Dairy Sci. 93:1616-1624. https://doi.org/10.3168/jds.2009-2555.

Schroeder, J. W. 2004. Silage Fermentation and Preservation. AS1254. Accessed Jan. 23, 2017. https://www.ag.ndsu.edu/pubs/ ansci/range/as1254.pdf.

Shaver, R. D., J. G. Lauer, J. G. Coors, and P. C. Hoffman. 2006. MILK2006 Corn Silage: Calculates TDN-1x, NEL-3x, Milk per ton, and Milk per acre. Milk2006corn silagev1.xls. Accessed Jan. 20, 2017. http://shaverlab.dysci.wisc.edu/spreadsheets/.

Spadaro, D., M. P. Bustos-Lopez, M. L. Gullino, S. Piano, E. Tabacco, and G. Borreani. 2015. Evolution of fungal populations in corn silage conserved under polyethylene or biodegradable films. J. Appl. Microbiol. 119:510-520. https://doi.org/10.1111/jam.12852.

Spoelstra, S. F., M. G. Courtin, and J. A. C. Van Beers. 1988. Acetic acid bacteria can initiate aerobic deterioration of maize silage. J. Agric. Sci. 111:127-132.

Tabacco, E., and G. Borreani. 2002. Extent of aerobic deterioration in farm maize silage as affected by silo management. Pages 178-179 in Proc. 13th Int. Silage Conf., Auchincruive, Scotland, UK.
Tabacco, E., S. Piano, A. Revello-Chion, and G. Borreani. 2011a. Effect of Lactobacillus buchneri LN4637 and Lactobacillus buchneri LN40177 on the aerobic stability, fermentation products, and microbial populations of corn silage under farm conditions. J. Dairy Sci. 94:5589-5598. https://doi.org/10.3168/jds.2011-4286.

Tabacco, E., F. Righi, A. Quarantelli, and G. Borreani. 2011b. Dry matter and nutritional losses during aerobic deterioration of corn and sorghum silages as influenced by different lactic acid bacteria inocula. J. Dairy Sci. 94:1409-1419. https://doi.org/10.3168/jds $.2010-3538$.

Teller, R. S., R. J. Schmidt, L. W. Whitlow, and L. Kung Jr. 2012. Effect of physical damage to ears of corn before harvest and treatment with various additives on the concentration of mycotoxins, silage fermentation, and aerobic stability of corn silage. J. Dairy Sci. 95:1428-1436. https://doi.org/10.3168/jds.2011-4610.

Thomas, E. 2007. AM vs. PM alfalfa harvest. Miner Institute Farm Report. August, 2007.

Thomas, E. 2013. Preserving forage quality from windrow to feedbunk. Scientific presentation 2013 VSFA Convention and Nutritional Management "Cow College", Feb. 20-22, Roanoke, VA.

Thomas, M. E., J. L. Foster, K. C. McCuistion, L. A. Redmon, and R. W. Jessup. 2013. Nutritive value, fermentation characteristics, and in situ disappearance kinetics of sorghum silage treated with inoculants. J. Dairy Sci. 96:7120-7131. https://doi.org/10.3168/ jds.2013-6635.

Tremblay, G. F., C. Morin, G. Bélanger, A. Bertrand, Y. Castonguay, R. Berthiaume, and G. Allard. 2014. Silage fermentation of PMand AM-cut alfalfa wilted in wide and narrow swaths. Crop Sci. 54:439-452. https://doi.org/10.2135/cropsci2013.07.0443.

Undersander, D. 2006. Minimizing wheel-track effects on forages. in Silage for Dairy Farms: Growing, Harvesting, Storing and Feeding Conference Proceedings (NRAES-181), Natural Resource, Agriculture and Engineering Service, Ithaca, NY.

Villa, A. F., A. P. Melendez, J. E. Carulla, M. L. Pabon, and E. A. Cardenas. 2010. Study of microbiological and nutritional quality of corn silage in two Colombian ecosystems. Rev. Colomb. Cienc. Pecu. 23:65-77.

Visser, B. 2005. Forage density and fermentation variation: A survey of bunkers, piles, and bags across Minnesota and Wisconsin dairy farms. Pages 233-240 in Proc. Four State Dairy Nutrition and Management Conf., MWPS-4SD18, Dubuque, IA.

Vissers, M. M. M., F. Driehuis, M. C. Te Giffel, P. De Jong, and J. M. G. Lankveld. 2007. Concentrations of butyric acid bacteria spores in silage and relationships with aerobic deterioration. J. Dairy Sci. 90:928-936.

Wambacq, E., I. Vanhoutte, K. Audenaert, L. De Gelder, and G. Haesaert. 2016. Occurrence, prevention and remediation of toxigenic fungi and mycotoxins in silage: A review. J. Sci. Food Agric. 96:2284-2302. https://doi.org/10.1002/jsfa.7565.

Wang, C., and N. Nishino. 2013. Effects of storage temperature and ensiling period on fermentation products, aerobic stability and microbial communities of total mixed ration silage. J. Appl. Microbiol. 114:1687-1695. https://doi.org/10.1111/jam.12200.

Weinberg, Z. G., Y. Chen, and R. Solomon. 2009. The quality of commercial wheat silages in Israel. J. Dairy Sci. 92:638-644. https:// doi.org/10.3168/jds.2008-1120.

Weinberg, Z. G., and R. E. Muck. 1996. New trends and opportunities in the development and use of inoculants for silage. FEMS Microbiol. Rev. 19:53-68.

Weinberg, Z. G., G. Szakacs, G. Ashbell, and Y. Hen. 2001. The effect of temperature on the ensiling process of corn and wheat. J. Appl. Microbiol. 90:561-566.

Weiss, K., B. Kroschewski, and H. Auerbach. 2016. Effect of air exposure, temperature and additives on fermentation characteristics, yeasts count, aerobic stability and volatile organic compounds in corn silage. J. Dairy Sci. 99:8053-8069. https://doi.org/10.3168/ jds.2015-10323.

Whitlock, L. A., T. Wistuba, M. K. Siefers, R. V. Pope, B. E. Brent, and K. K. Bolsen. 2000. Effect of level of surface-spoiled silage on the nutritive value of corn silage-based rations. J. Dairy Sci. 83(Suppl. 1):110. (Abstr.) 
Wilkinson, J. M., K. K. Bolsen, and C. J. Lin. 2003. History of silage. Pages 1-30 in Silage Science and Technology (Agronomy Series No. 42). Buxton D. R., R. E. Muck, and H. J. Harrison, ed. American Society of Agronomy, Madison, WI.

Wilkinson, J. M., and D. R. Davies. 2013. The aerobic stability of silage: key findings and recent developments. Grass Forage Sci. 68:1-19. https://doi.org/10.1111/j.1365-2494.2012.00891.x.

Wilkinson, J. M., and J. S. Fenlon. 2014. A meta-analysis comparing standard polyethylene and oxygen barrier film in terms of losses during storage and aerobic stability of silage. Grass Forage Sci. 69:385-392. https://doi.org/10.1111/gfs.12087.

Wilkinson, J. M., and R. Rimini. 2002. Effect of triple co-extruded film on losses during the ensilage of ryegrass. Pages 168-169 in Proc. 13th Int. Silage Conf. L. Gechie and C. Thomas, ed. Auchincruive, Scotland.

Williams, A. G., J. F. Lowe, and D. V. H. Rees. 1994. The effect of oxygen concentration on changes in the microbial population, temperature and dry matter content in grass silage. Grass Forage Sci. 49:183-191.
Windle, M., and L. Kung Jr. 2013. The effect of a feed additive on the feeding value of a silage-based TMR exposed to air. J. Dairy Sci. 91 (E-Suppl. 1):16.

Woolford, M. K. 1990. The detrimental effect of air on silage. J. Appl. Bacteriol. 68:101-116.

Yamamoto, Y., P. Gaudu, and A. Gruss. 2011. Oxidative stress and oxygen metabolism in lactic acid bacteria. Pages 91-102 in Lactic Acid Bacteria and Bifidobacteria: Current Progress in Advanced Research. K. Sonomoto and A. Yokota, ed. Caister Scientific Press, Norfolk, UK.

Zhou, Y., P. Drouin, and C. Lafrenière. 2016. Effect of temperature $\left(5-25^{\circ} \mathrm{C}\right)$ on epiphytic lactic acid bacteria populations and fermentation of whole-plant corn silage. J. Appl. Microbiol. 121:657-671. https://doi.org/10.1111/jam.13198.

Zimmer, E. 1980. Efficient silage systems. Pages 176-194 in - Forage Conservation in the '80s - Occasional Symposium, British Grassland Society Conference, No. 11, Brighton, UK. 